\title{
7. THE LESSER ANTILLES ISLAND ARC: STRUCTURE AND GEODYNAMIC EVOLUTION ${ }^{1}$
}

\author{
Philippe Bouysse, Service Géologique National, Bureau de Recherches Géologiques et Minières²
}

\begin{abstract}
Extensive onshore fieldwork combined with marine geology cruises carried out in the Lesser Antilles Ridge (Barbados area excepted) provide new insights to the physiography and structure of this island arc and permit a speculative reconstitution of the evolution of the area since the Late Jurassic.

The present configuration of the Lesser Antilles island arc is due to the westward underthrusting of the Atlantic oceanic crust under the Caribbean Plate. The rate of convergence of this active margin is slow: $2.2 \mathrm{~cm} / \mathrm{yr}$.

Most significant is the sharp contrast between the northern and southern Lesser Antilles. In the northern half, the basement of the ridge is thought to be Mesozoic and connected to the Greater Antilles island arc. In the southern half (south of Guadeloupe archipelago), the island arc existed only since the Eocene. From Grenada to Martinique the subduction pattern was not modified from Eocene until Present. From Guadeloupe to the northern end of the Lesser Antilles, two volcanic ridges were successively superimposed on the older island arc basement: an outer (eastern) arc, volcanically active from Eocene to possibly early Miocene, and an inner (western) arc, volcanically active from late Miocene to Present. In between, from Martinique to Guadeloupe, the situation was transitional. The westward jump of the volcanic line that occurred in the northern part of the Lesser Antilles during the Miocene may have been consecutive to the interaction of an Atlantic fracture zone ridge (Barracuda) with the subduction process.

The relation between Aves Swell and Lesser Antilles Ridge is discussed and the Grenada Basin is interpreted as a trapped back-arc basin.
\end{abstract}

\section{INTRODUCTION}

The Lesser Antilles arc to the north and the South Sandwich archipelago (Scotia Arc) to the south are the only two active island arcs of the Atlantic Ocean, other similar features being mainly concentrated on the western side of the Pacific Ocean.

Geological studies of the islands started long ago, but the submarine areas of the Ridge, in a strict sense (i.e., excluding the neighboring basins or sedimentary accumulations like Barbados Ridge), had been, until recently, little surveyed. The ARCANTE project, conducted by the Bureau de Recherches Géologiques et Minières (French Geological Survey), is devoted to the onshore and offshore geological and structural study of the Lesser Antilles arc, with a special emphasis on the French West Indies areas. Our field surveys and marine geology cruises have provided some new insights in to the geology of some islands (particularly Martinique, Guadeloupe, les Saintes, Marie-Galante, la Désirade, St. Bartholomew, St. Martin, Redonda) and to the physiographic and structural pattern of most of the Lesser Antilles submarine ridge. In this paper, I will try to summarize results and ideas developed by our ARCANTE research group (particularly, Andreieff et al., 1976; Westercamp and Mervoyer, 1976; Andreieff et al., 1979; Bouysse, 1979; Westercamp, 1979, Bouysse, Andreieff, and Westercamp, in press; Bouysse, Schmidt-Effing, and Westercamp, 1983; Bouysse and Guennoc, 1983; and Westercamp and Andreieff, in press).

\footnotetext{
${ }^{1}$ Biju-Duval, B., Moore, J. C., et al., Init. Repts. DSDP, 78A: Washington (U.S. Govt. Printing Office).

2 Address: Service Géologique National, Bureau de Recherches Géologiques et Minières, B.P. 6009,45060 Orleans Cedex, France.
}

Because the Lesser Antilles volcanic arc is the main physiographic feature of the eastern Caribbean convergent margin, this chapter is intended as a background for Volume 78A. Although the chapter was elaborated in the framework of personal concepts dealing with the structural evolution of the region, I hope that it will be of some use in understanding the geological environment of the Leg 78A drill sites.

\section{GENERAL SETTING}

The Lesser Antilles island arc (Fig. 1), comprising a score of major islands, is about $850 \mathrm{~km}$ long, with a radius of curvature of about $450 \mathrm{~km}$. It stretches from the South American continental margin to the Anegada Passage, which marks the boundary with the Greater Antilles. It underlines the eastern boundary of the Caribbean Plate (Malfait and Dinkelman, 1972; Jordan, 1975; Tomblin, 1975; Bowin, 1976; Ladd, 1976; Dorel, 1978; Burke et al., 1978) underthrust, in a subduction zone, by the oceanic crust of the western Atlantic Ocean.

The Lesser Antilles Ridge has been described as a double arc, coalescent in its southern part and diverging at the latitude of Dominica (Martin-Kaye, 1969, Fink, 1972). The outer arc (to the east) was thought to be volcanically active from the Eocene to early Miocene, and the inner arc or recent arc (to the west) active from the late Miocene to Present. The northeastern branch, where only older volcanic rocks crop out on some of the islands, is called the Limestone Caribbees (Marie-Galante, Grande-Terre of Guadeloupe, la Désirade, Antigua, Barbuda, St. Bartholomew, St. Martin, Tintamarre, Anguilla, Dog, and Sombrero). The rest of the archipelago, which bears the active or recent volcanoes, is called the Volcanic Caribbees (Fig. 2) (Grenada, Grenadines, St. Vincent, St. Lucia, Martinique, Dominica, les Saintes, 


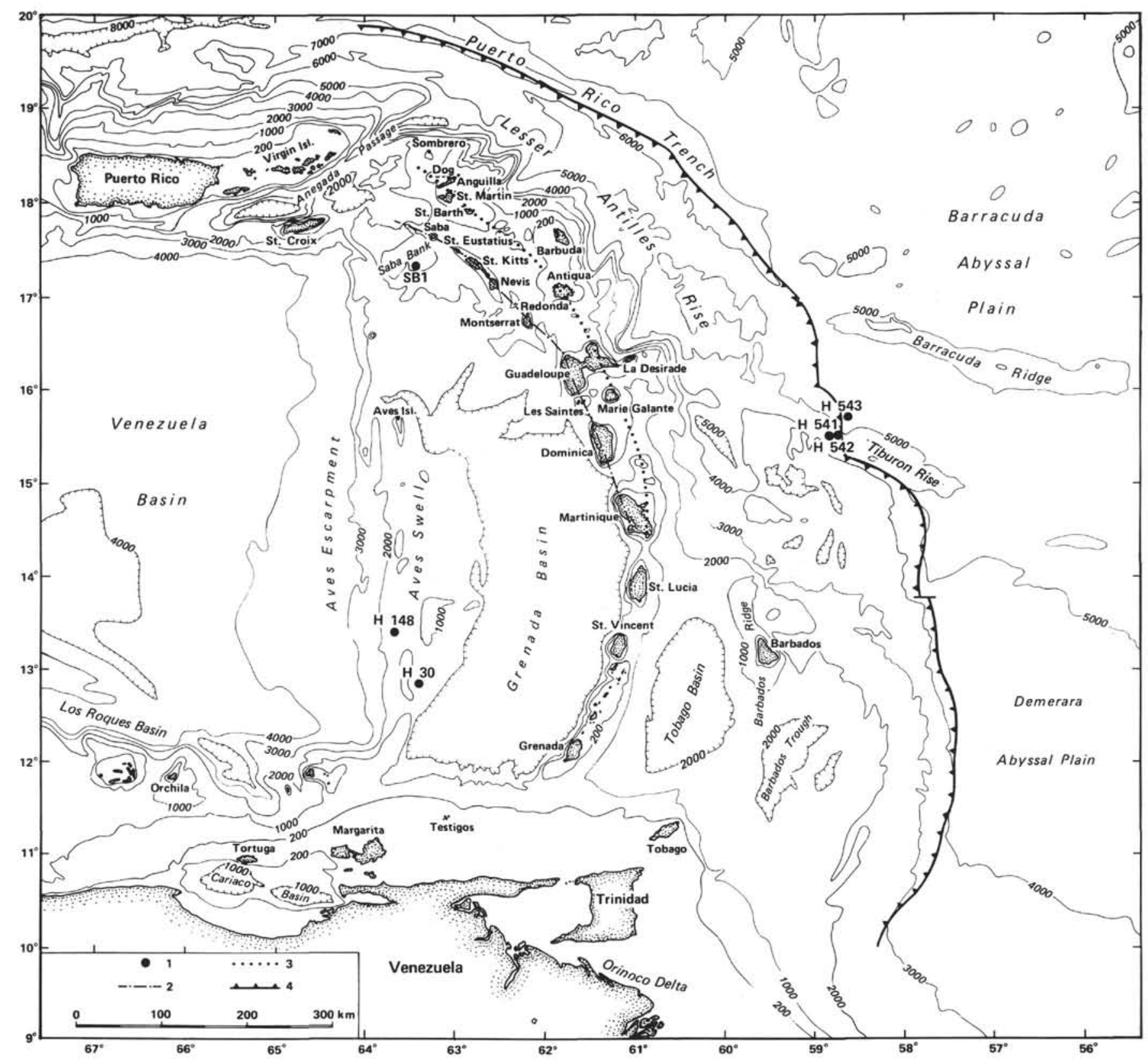

Figure 1. Eastern Caribbean. (Bathymetry [isobaths: $200 \mathrm{~m}$ and every $1000 \mathrm{~m}$ ], simplified from Case and Holcombe [1980], is slightly modified. For toponymy and detailed bathymetry between St. Lucia and Anguila, refer to Fig. 3. Key: $1=$ drill sites [SB1 = Saba Bank exploratory well; $\mathrm{H}=$ DSDP holes]; 2 = inner arc; $3=$ outer arc; $4=$ deformation front [after Case and Holcombe, 1980].)

Basse-Terre of Guadeloupe, Montserrat, Redonda, Nevis, St. Kitts, St. Eustatius, and Saba).

To the west, from Guadeloupe southward, the Lesser Antilles arc ridge has steep slopes delineating the western arcuate border of the Grenada Basin, whose maximum depth is $2800 \mathrm{~m}$. This Basin is filled with about 7 $\mathrm{km}$ of sediments (Uchupi, 1975). Farther to the west, the Grenada Basin is bounded by the Aves Swell, which is thought to have been an active island arc from Late Cretaceous to Paleocene (Nagle, 1972; Fox and Heezen, 1975; Clark et al., 1978). The western side of Aves Swell is connected to the Venezuelan Basin by the Aves Escarpment, a $600-\mathrm{km}$-long rectilinear feature joining the Venezuelan continental margin to the Greater Antilles.
On the eastern side of the Lesser Antilles are two main morphostructures. One is the southeast termination of the Puerto Rico Trench, more than $6000 \mathrm{~m}$ deep, which is linked to the arc ridge by the Lesser Antilles Rise. The Trench progressively merges southward into the Barbados accretionary prism (Mascle et al., 1977), which has a maximum thickness of about $20 \mathrm{~km}$ (Westbrook, 1975). The prism culminates at Barbados Island and is made of sediments mainly derived from the South American rivers (the Orinoco, and later, the Amazon).

An intriguing problem was raised when Fink (1968) reported a $\mathrm{K}-\mathrm{Ar}$ age of $142 \mathrm{Ma}$ (Upper Jurassic) for a trondhjemite outcropping in the center of la Désirade, and occurrences of pillow basalts associated with cherts 


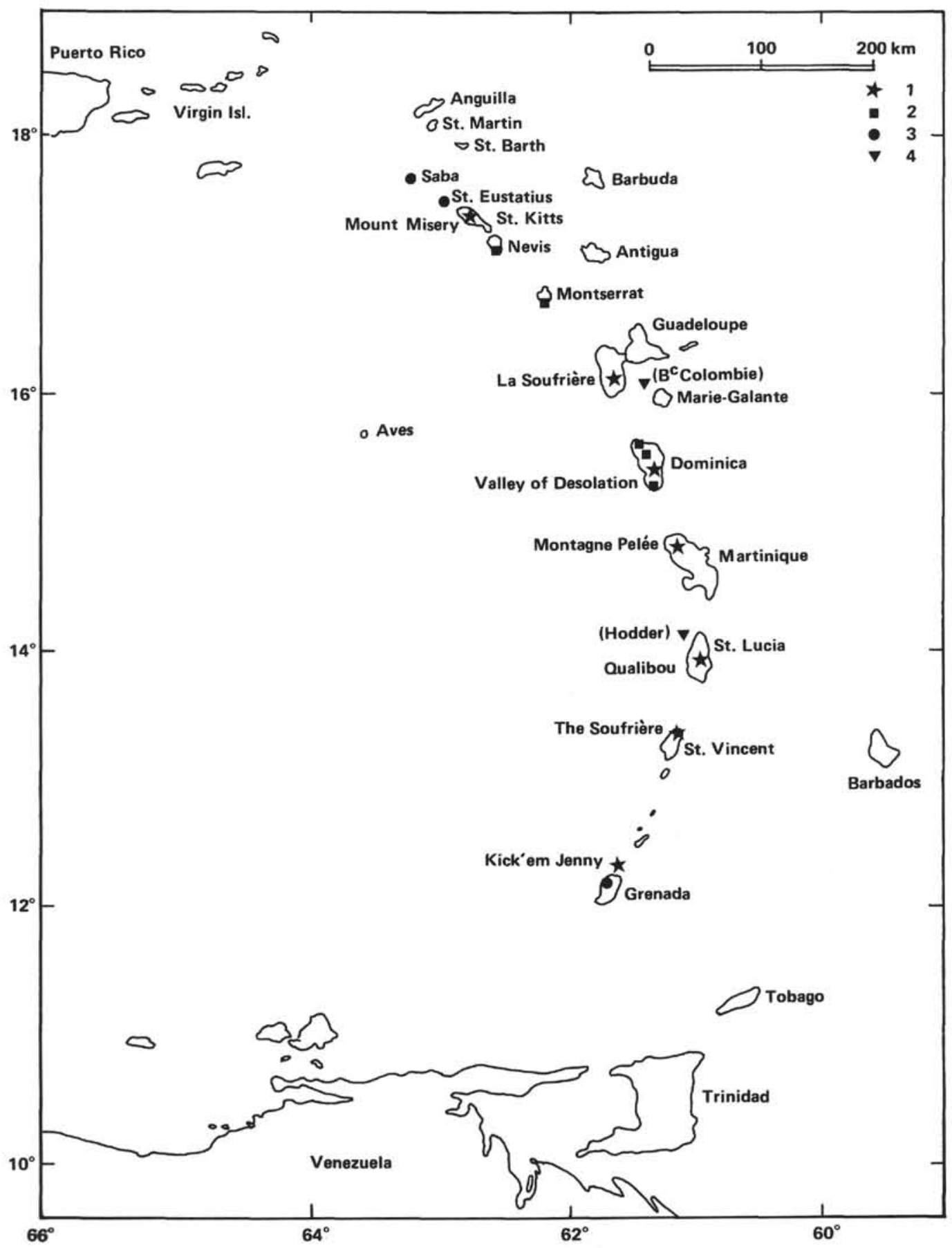

Figure 2. Location of the active volcanoes of the Lesser Antilles, modified after Robson and Tomblin (1966). (Key: 1 = volcanoes with recorded eruptions; 2 = volcanoes exhibiting solfataric or fumarolic activity, with no recorded eruptions; 3 = volcanoes with well-preserved morphology that probably have erupted within the past few thousand years; 4 = previously postulated active submarine volcanoes, in reality nonexistent. $\mathrm{B}^{\mathrm{c}}$ Colombie $=$ Colombie Bank.)

to the northeast of the same island. This age, disputed by some authors (Dinkelman and Brown, 1977; Briden et al., 1979), and the so-called "ophiolitic complex" led to various tentative interpretations concerning the evolution of the East Caribbean area. The most favored hypothesis conceives of la Désirade as a slice of oceanic crust (either of Atlantic or Caribbean origin) that was uplifted or scraped off, and piled up, during the Cenozoic, against the Lesser Antilles Ridge (Mattinson et al.,
1973 and 1980; Fox and Heezen, 1975; Dinkelman and Brown, 1977). The alternative hypothesis is that la Désirade might have been part of the Greater Antilles island arc encompassing, possibly, the whole Lesser Antilles area to the South American border (Fink, 1968 and 1972; Fink et al., 1971).

The present configuration of the Lesser Antilles arc is mirrored by the recent volcanoes of the inner arc. They are distributed along a narrow alignment, actually not 
as a perfect arcuate pattern, but showing three more or less rectilinear and equivalent sections (Fig. 11D), according to an insular segmentation (see Stoiber and Carr, 1973; Ranneft, 1976; Marsh, 1979). The central segment, bearing the three largest islands of the archipelago (Martinique, Dominica, and Basse-Terre of Guadeloupe), is very straight. This tripartite subdivision is probably related to a major segmentation of the Wadati-Beninoff zone in three slabs (Tomblin, 1975; Dorel, 1978), sinking no deeper than $190 \mathrm{~km}$ (earthquake depth limit). From new seismic data supplied by Dorel (1978, 1981), it seems that the Atlantic crust, underthrust below the Caribbean crust, is presently part of the South America Plate. This Plate is probably decoupled, at present, from the North America Plate by a slight right-lateral movement $(0.2 \mathrm{~cm} / \mathrm{yr}$.) along a transform fault connected to the east-west segment of the Puerto Rico Trench. The continuity of north-south trending magnetic anomalies crossing Barracuda Ridge (Peter and Westbrook, 1976) precludes the possibility of placing the boundary between North America and South America plates along this fracture zone, as previously stated (see for example, Bowin, 1976).

The Lesser Antilles is a slow-moving active margin with a convergence rate of about $2.2 \mathrm{~cm} / \mathrm{yr}$. (Dorel, 1978 and 1981; Tovish and Schubert, 1978). This value is low when compared to other convergent margins and, therefore, the volcanic and seismic effects of the subduction are relatively subdued.

In Table 1, the recent volcanic activity of the Lesser Antilles is compared to two other island arcs and to one continental arc (cordillera) of approximately the same length ( 5 to $6^{\circ}$ of latitude) but with different rates of subduction. The rather low seismicity of the Lesser Antilles has been discussed by Dorel et al. (1971) and Dorel (1978 and 1981); the earthquake magnitudes greater than 6 are uncommon. Under the present volcanic axis, the depth of the subducted slab is about $100 \mathrm{~km}$ to the north and the south, and about $120 \mathrm{~km}$ for the central segment.

Historic recorded eruptive or fumarolic activity (since the seventeenth century) occurred (Fig. 2) at Kick'em Jenny

Table 1. Eruptive activity of four convergent margins between 1900 and 1980 (from Simkin et al., 1981).

\begin{tabular}{lccc}
\hline \multicolumn{1}{c}{$\begin{array}{c}\text { Convergent } \\
\text { margins }\end{array}$} & $\begin{array}{c}\text { Erupting } \\
\text { volcanoes }\end{array}$ & $\begin{array}{c}\text { Number of } \\
\text { eruptions }\end{array}$ & $\begin{array}{c}\text { Rate of } \\
\text { convergence } \\
\text { (cm/yr.) }\end{array}$ \\
\hline $\begin{array}{l}\text { Lesser Antilles } \\
\text { Marianas }\end{array}$ & 4 & 16 & 2 \\
$\begin{array}{c}\text { New Hebrides } \\
\text { (Vanuatu) }\end{array}$ & 10 & 31 & 2 to 6 \\
$\begin{array}{c}\text { Middle America } \\
\text { (Guatemala to }\end{array}$ & 19 & 145 & 9 to 13 \\
$\quad$ Costa Rica) & & 58 & \\
\hline
\end{tabular}

Note: The four convergent margins, of approximately the same length, are compared with the convergence velocity (rounded values from Molnar and Atwater, 1978; Tovish and Schubert, 1978). Out of the 16 eruptions of the Lesser Antilles, 9 have been recorded from the very young submarine volcano, Kick'em Jenny (between 1938 and 1977). (a submarine volcano, north of Grenada), Soufrière of St. Vincent, Qualibou caldera in St. Lucie, Montagne Pelée in Martinique, Valley of Desolation in Dominica, la Soufrière of Guadeloupe, and Mount Misery in St. Kitts (Robson and Tomblin, 1966). Although relatively less frequent, some eruptions have had very dramatic consequences, such as the 1902 eruption of Montagne Pelée, killing the 28,000 inhabitants of St. Pierre. The most recent eruptions occurred in 1976 at la Soufrière of Guadeloupe, in 1977 at the Kick'em Jenny (Sigurdsson and Sparks, 1979), as well as in 1979 for the Soufrière of St. Vincent.

\section{STRUCTURE AND SUBMARINE MORPHOLOGY OF THE ISLAND ARC}

The disposition and extension of the insular shelves and submarine banks are, to some extent, a good mirror of the structure of the island arc (Figs. 1 and 3). These marine terraces are built up by Pliocene-Quaternary shallow-water limestones in which algal debris forms the dominant component.

\section{Southern Segment (Fig. 1)}

In the southern part of the arc, the slopes looking toward the Grenada Basin are rather steep, contrasting with the gentler ones of the Atlantic side, which are connected with the Barbados accretionary prism. From Grenada to St. Lucia, the arc is narrow with only one volcanic ridge. The width of the insular shelves (islands included) is less than $28 \mathrm{~km}$. Around St. Lucia and St. Vincent, the shelves delineate a rather limited "crown." By contrast, only one elongated (170-km-long) terrace encompasses Grenada and the Grenadines archipelago. Globally considered, the islands and islets are made of volcanic formations whose dated effusives span from 21 Ma (early Miocene) to Present (Briden et al., 1979) and of sediments and pyroclastic tuffs ranging from possibly early or middle Eocene (but surely late Eocene) to early Miocene (Martin-Kaye, 1969).

In Martinique, the eruptive centers migrated progressively from a prebasal Miocene igneous substratum in the east, to Quaternary volcanics in the west (Andreieff et al., 1976; Gérard et al., 1981). The oldest K-Ar date is $27 \mathrm{Ma}^{3}$ (late Oligocene); the 36-Ma age supplied by Nagle et al. (1976) was not confirmed (J. C. Baubron, personal communication, 1981). The Martinique shelf is relatively well developed to the northeast, and north of the island the outer and inner arcs diverge.

\section{Outer Arc}

Contrary to the interpretation of Fink (1972), there is no offset of the outer arc axis off Dominica. In fact, a curvilinear alignment, more or less continuous, of submarine banks (guyotlike features, with an igneous core) and islands where middle Eocene to Oligocene volcanic

\footnotetext{
${ }^{3}$ The dating of the stratigraphic boundaries (Neogene excluded) adopted in this paper is quoted from the latest revised scales (Odin and Curry, 1981; Odin and Kennedy, 1982; Odin, 1982).
} 


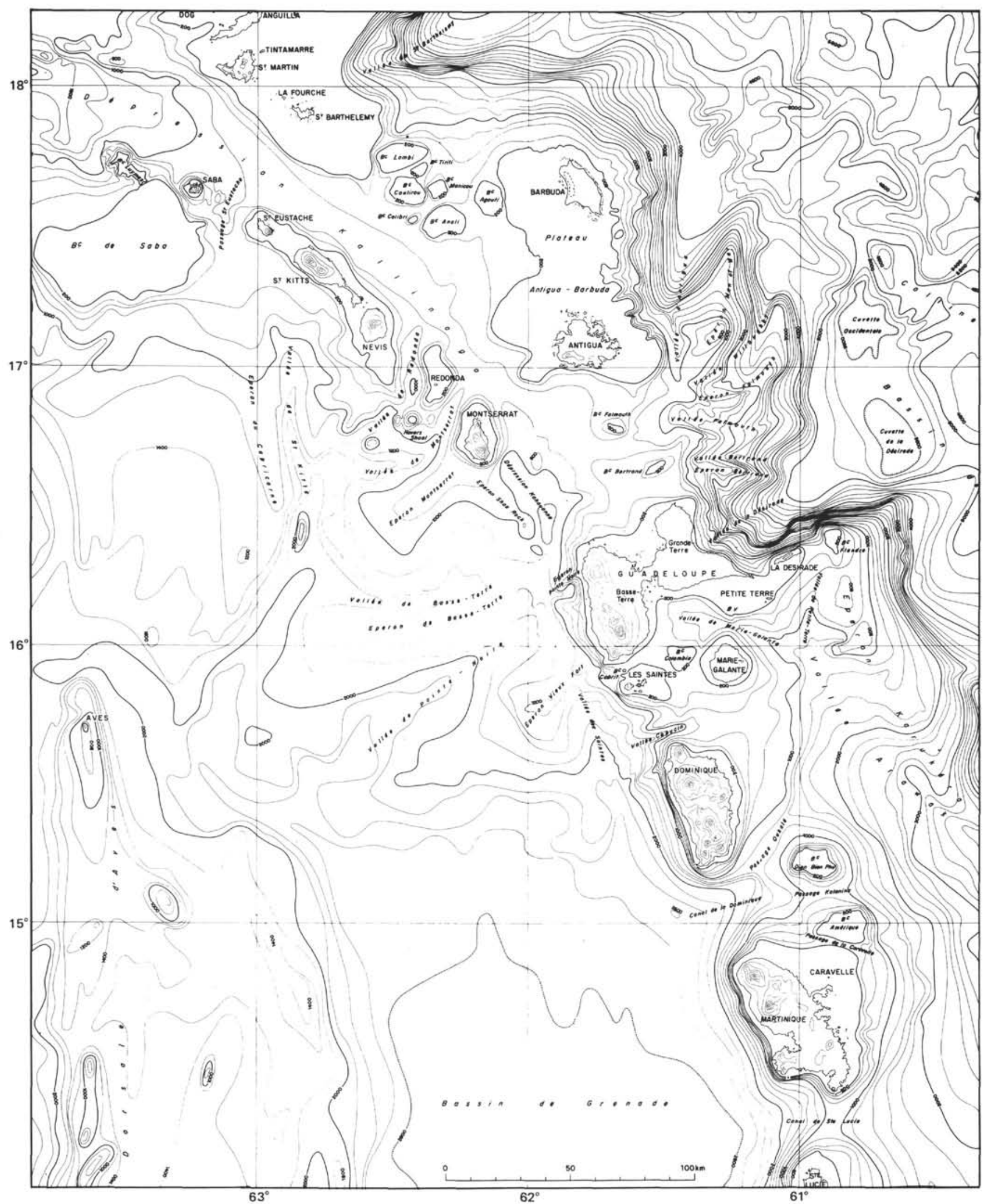

Figure 3. Bathymetric sketch between St. Lucia and Anguilla (ARCANTE 1 cruise) (modified from Bouysse, 1979). (Contour interval is $200 \mathrm{~m}$ [offshore and onshore]. For bathymetric data used and new physiographic names, see Bouysse [1979]. B.V. = Banc des Vaisseaux. Translation: $B^{\mathfrak{c}}=$ bank; bassin = basin; colline $=$ hill; cuvette = small basin; dorsale $=$ ridge; éperon $=$ spur; fosse $=$ trench; vallée $=$ valley.) 
effusives or intrusives generally crop out (Bouysse, 1979) can be followed. The row of the outer arc is made up of the following succession (Fig. 3):

Amérique and Dien Bien Phu banks (Fig. 4)

Marie-Galante, blanketed with Pliocene-Quaternary reefal limestones (in October, 1981, extremely restricted basal outcrops of upper Miocene and lower Pliocene volcanic tuffs and foraminifer limestones were discovered here-(Andreieff et al., in press)

Grande-Terre of Guadeloupe, the basement of which is completely concealed by Pliocene-Quaternary limestones (Andreieff and Cottez, 1976)

Bertrand and Falmouth banks

Antigua, consisting of upper Eocene to lower Oligocene lava flows and volcaniclastic deposits overlain by the Antigua Formation limestones (Martin-Kaye, 1969; Frost and Weiss, 1979) of the basal upper Oligocene (Globigerina ampliapertura Zone; P. Andreieff, personal communication, 1982); hence some $\mathrm{K}-\mathrm{Ar}$ radiometric ages, supplied by Nagle et al. (1976) -20.0 and 24.0 Ma-and by Briden et al. (1979)-23.2 $\mathrm{Ma}-$ seem to be too young

the seven Animal banks: Agouti, Anoli, Colibri, Coulirou, Manicou, Titiri, and Lambi (Bouysse, 1979)

St. Bartholomew (= St. Barth), where the eruptive episode (with limestone intercalations) was restricted to a short period of 2 to $3 \mathrm{Ma}$ in the middle Eocene (Andreieff, 1982; Westercamp and Andreieff, in press); these formations are

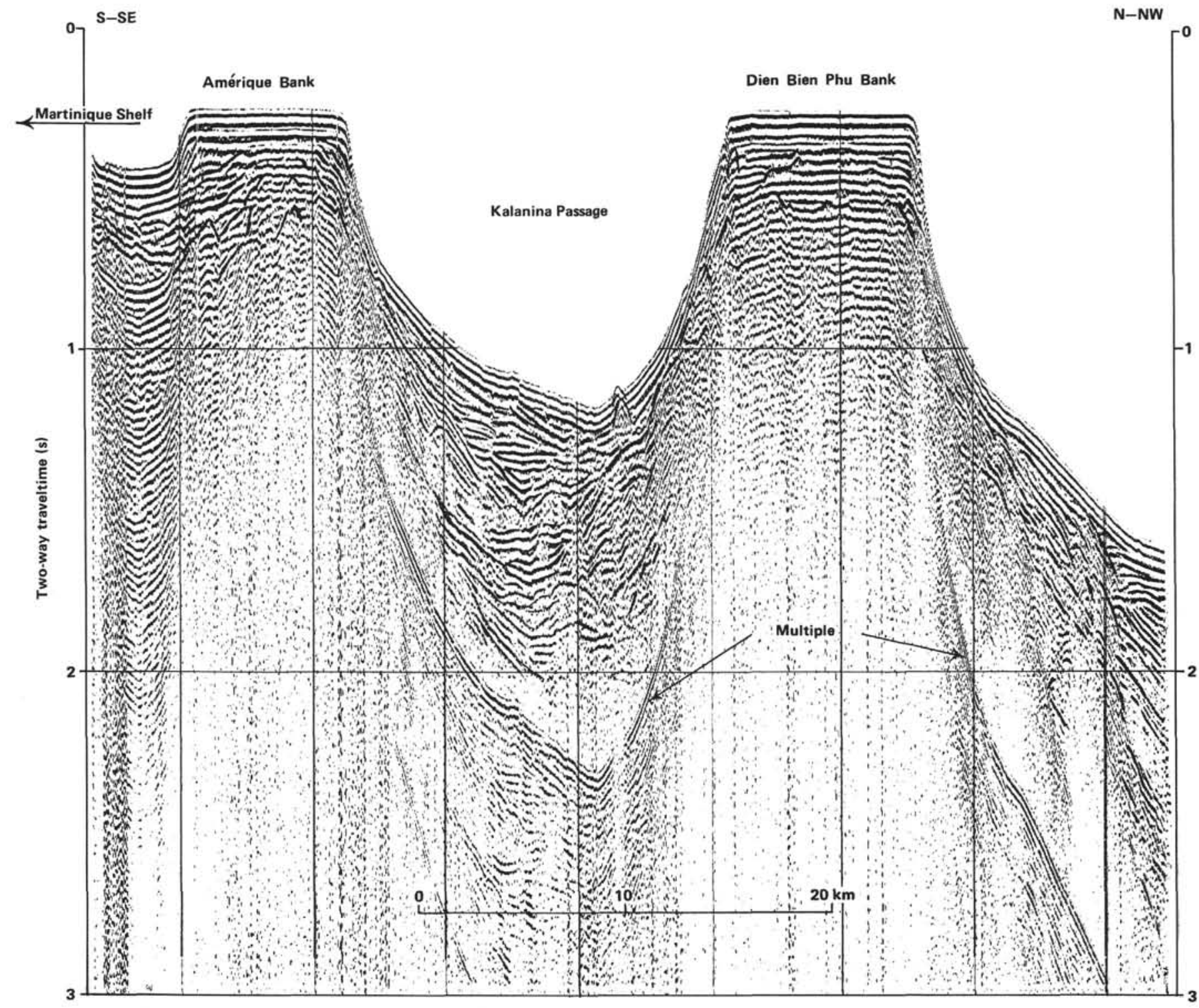

Figure 4. Water-gun seismic profile (ARCANTE 1 cruise) across the Amérique and Dien Bien Phu banks (N-NE of Martinique, Fig. 3). (Despite the interference with the multiple reflections, it is possible to infer a guyotlike structure for these platforms, with a Pliocene-Quaternary limestone cap. Some first reflection horizons have been underlined.) 
intruded by Oligocene plutonic rocks (24-32 Ma-Nagle et al., 1976; Briden et al., 1979)

St. Martin, having middle and upper Eocene volcaniclastics and sediments, upper Eocene to lower Oligocene intrusives (28.4-37.2 Ma), and upper Miocene limestones and marls (Nagle et al., 1976; Briden et al., 1979; Andreieff et al., 1981; Andreieff, 1982)

Anguilla, mainly made of a table of upper lower to basal middle Miocene deposits (Andreieff, 1982 ) overlying a poorly exposed volcanic basement

Dog, an islet geologically similar to Anguilla, and which is the northernmost emerged area displaying outer arc volcanic remains (Martin-Kaye, 1969)

Of the remaining Limestone Caribbees, two islands should not be ascribed to the outer arc, contrary to the assumption of former authors (Martin-Kaye, 1969; Fink, 1972; Butterlin, 1977). La Désirade and Barbuda are situated outside (to the east) of the row just described. La Désirade is made of a lower Pliocene tablelike calcareous plateau underlain by an igneous complex. As a result of recent detailed fieldwork (Westercamp, 1980; Bouysse, Schmidt-Effing, and Westercamp, 1983), we conclude that this basement was entirely originated by island-arc magmatic processes. The "central acid massif," where the trondhjemite crops out, is Upper Jurassic (Mattinson et al., 1973 and 1980). For the "northeast volcanic complex," including the so-called "ophiolitic" pillowed basalts and associated cherts (Fig. 5), the chemistry of the primary clinopyroxenes from the lavas is clearly consonant with an island-arc magmatism (Le Guen de Kerneizon et al., 1979). The radiolarian cherts indicate the Early Cretaceous (Hauterivian-Barremian; Bouysse, Schmidt-Effing, and Westercamp, 1983). The low-lying island of Barbuda is exclusively composed of Quaternary limestones (Martin-Kaye, 1969; A. Mascle, personal communication, 1982). Its igneous basement is unknown, but Eocene and Oligocene volcanics might also be missing, as at la Désirade. For Sombrero, closer to the outer arc, the situation is not clear. This islet is made of Pliocene-Quaternary reefal limestones (P. Andreieff, personal communication, 1982).

An outstanding feature, to the north of Guadeloupe, is the wide extension of the two insular shelves of Antigua-Barbuda $\left(4000 \mathrm{~km}^{2}\right)$ and of Anguilla-St. Barth $\left(4500 \mathrm{~km}^{2}\right)$.

\section{Inner Arc}

In the volcanically active inner arc north of Martinique, only Pliocene-Quaternary volcanic formations

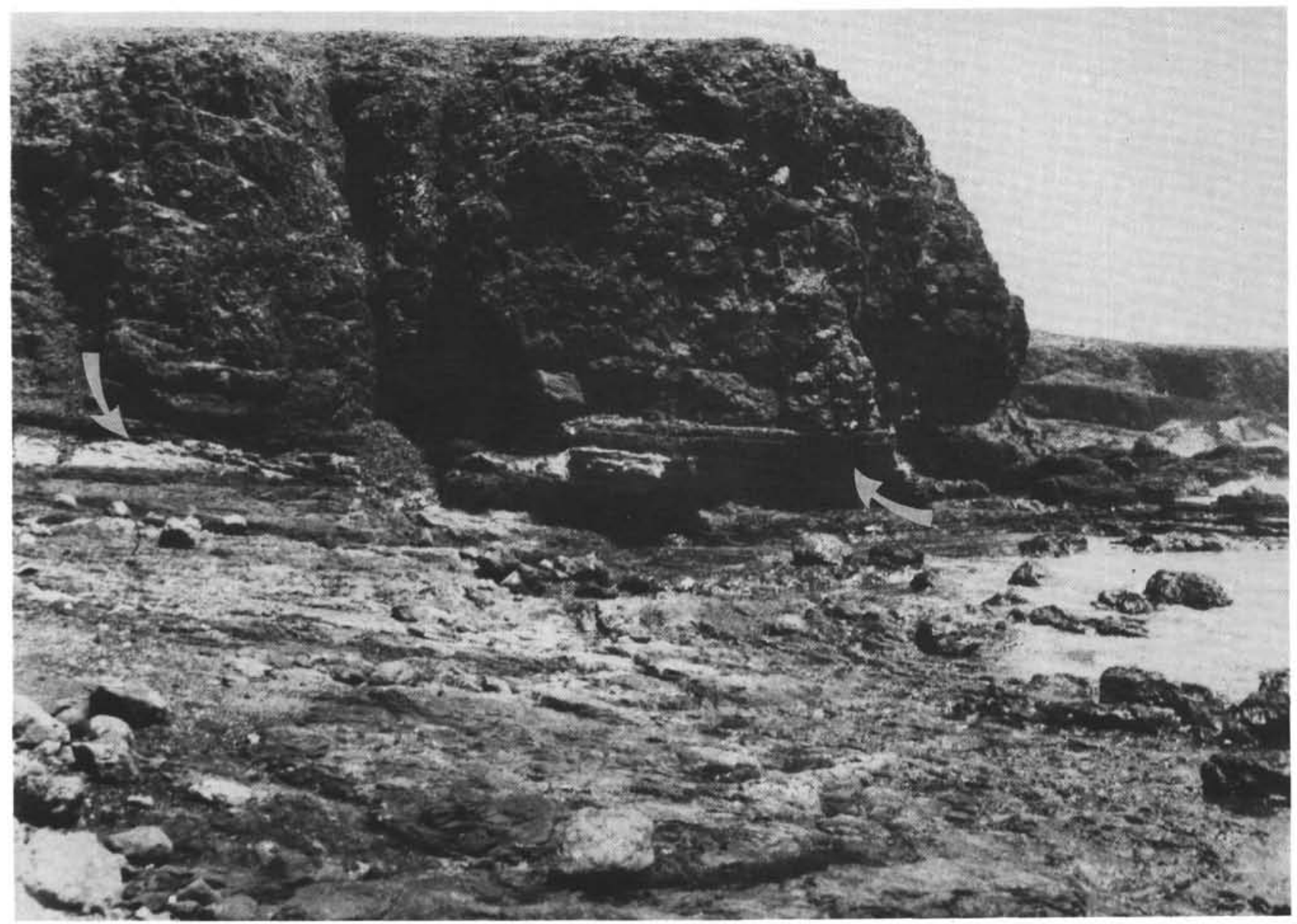

Figure 5. La Désirade Island (Guadeloupe archipelago), Pointe Mansenilier, northeastern coast. (Radiolarian cherts, near those at the base of the cliff [arrows], are Lower Cretaceous; they are overlain by pillowed basalts. This section belongs to the "northeast volcanic complex" of the island igneous basement.) 
crop out, except at St. Kitts where Baker $(1969,1981)$ claims a $7.5 \pm 2 \mathrm{Ma}$ date and at les Saintes where a maximum age of $6.2 \mathrm{Ma}$ was supplied by Javet and Alsac (1974) - both late Miocene dates. For other islands, scarce K-Ar determinations (Westercamp and Mervoyer, 1976; Briden et al., 1979) give values of 3.5 and $4.4 \mathrm{Ma}$ for the oldest ages in Basse-Terre of Gaudeloupe and in Montserrat, respectively, and only two dates in Dominica (1.1 and $1.8 \mathrm{Ma}$ ).

The shallow terraces of the inner arc have a more reduced size than those of the outer arc. But where volcanic activity is long extinct, as at les Saintes (2.8 Ma ago-Javet and Alsac, 1974) and Redonda (1.5 Ma agoBaubron et al., 1979), the submerged platforms have a significant extension with respect to the emerged areas. The small (less than $2 \mathrm{~km}^{2}$ ) but high $(300 \mathrm{~m})$ rocky islet of Redonda (Fig. 6) is a basaltic monogenetic volcano of the basal Pleistocene. It has pierced through the sedimentary terrace capping an older volcanic substratum. Its highly basic character is a rather uncommon feature in the Lesser Antilles and is probably related to a major transverse fault (Baubron et al., 1979). Nearby and to the southwest of Redonda, the Havers shoal is a guyot where lower Pliocene tuffitic limestones and an upper Pleistocene quartz-dacite crop out (Andreieff et al., 1979).

The inner arc terminates at the Luymes Bank, to the north of Saba Island (Bouysse et al., 1981). It is a small and elongated shoal made of a volcanic ridge capped with Pliocene-Quaternary sedimentary strata (Fig. 7).
Dredge hauls on its western flank recovered porphyritic andesites 3.6 Ma old (middle Pliocene). This age and the morphology of the Bank suggest that volcanic activity may have ended before the Pleistocene, so that the Island of Saba is presently the northernmost active center of the inner arc, although no historic eruptions have been recorded there.

Evidence for the existence of an older basement beneath the upper Neogene inner-arc buildup are middle Eocene neritic limestone boulders found in volcanic ejecta in the south part of Nevis (Hutton, 1968).

\section{Intra-Arc Depression}

In the northern half of the archipelago, between the outer and inner arcs, an intra-arc trough, named Kallinago depression (Bouysse, 1979), stretches from the north of Guadeloupe to the Anegada Passage (Fig. 1). The trough is narrow (20-50 km wide), about $250 \mathrm{~km}$ long, and ranges in depth from about 600 to $2000 \mathrm{~m}$ at its north end. Two transverse swells, located between Redonda and Antigua, and between St. Eustatius and the southern tip of Anguilla-St. Barth shelf, subdivide this depression into three parts (Fig. 10). The maximum sedimentary infilling is not known (more than $2 \mathrm{~km}$ ?), but the post-middle Miocene sediments are less than 1 $\mathrm{km}$ thick except, locally, to the north of Guadeloupe and at the northern end of the trough (Bouysse and Guennoc, 1983).

The structure of this depression was probably initiated, at least with its gross characteristics, by the jump

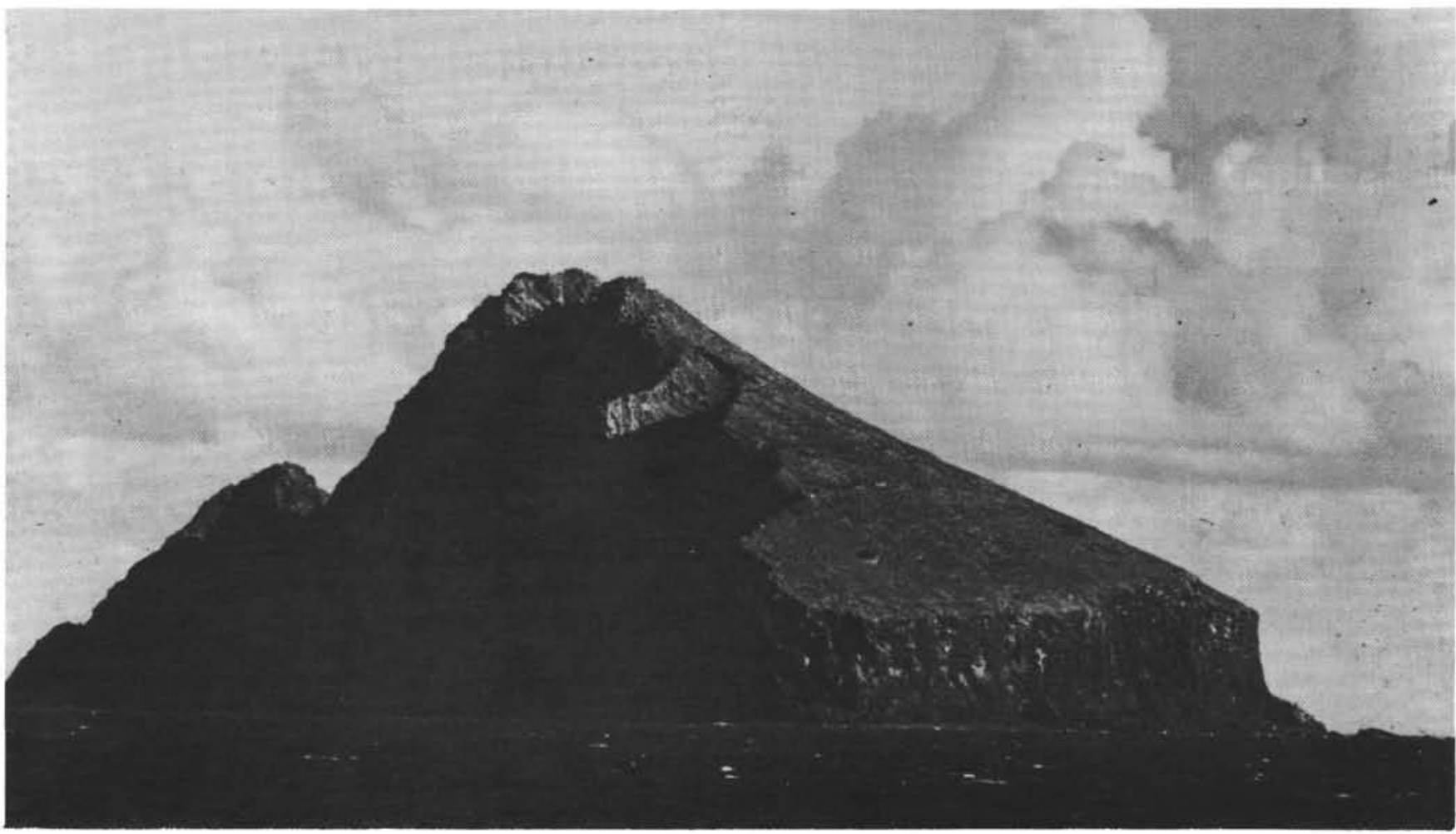

Figure 6. Redonda islet (inner arc, recent volcanoes) with west-northwest facing cliffs. (This half conical, 300-m-high, monogenetic volcano has been extinct since about $1.5 \mathrm{Ma}$.) 
N-NE

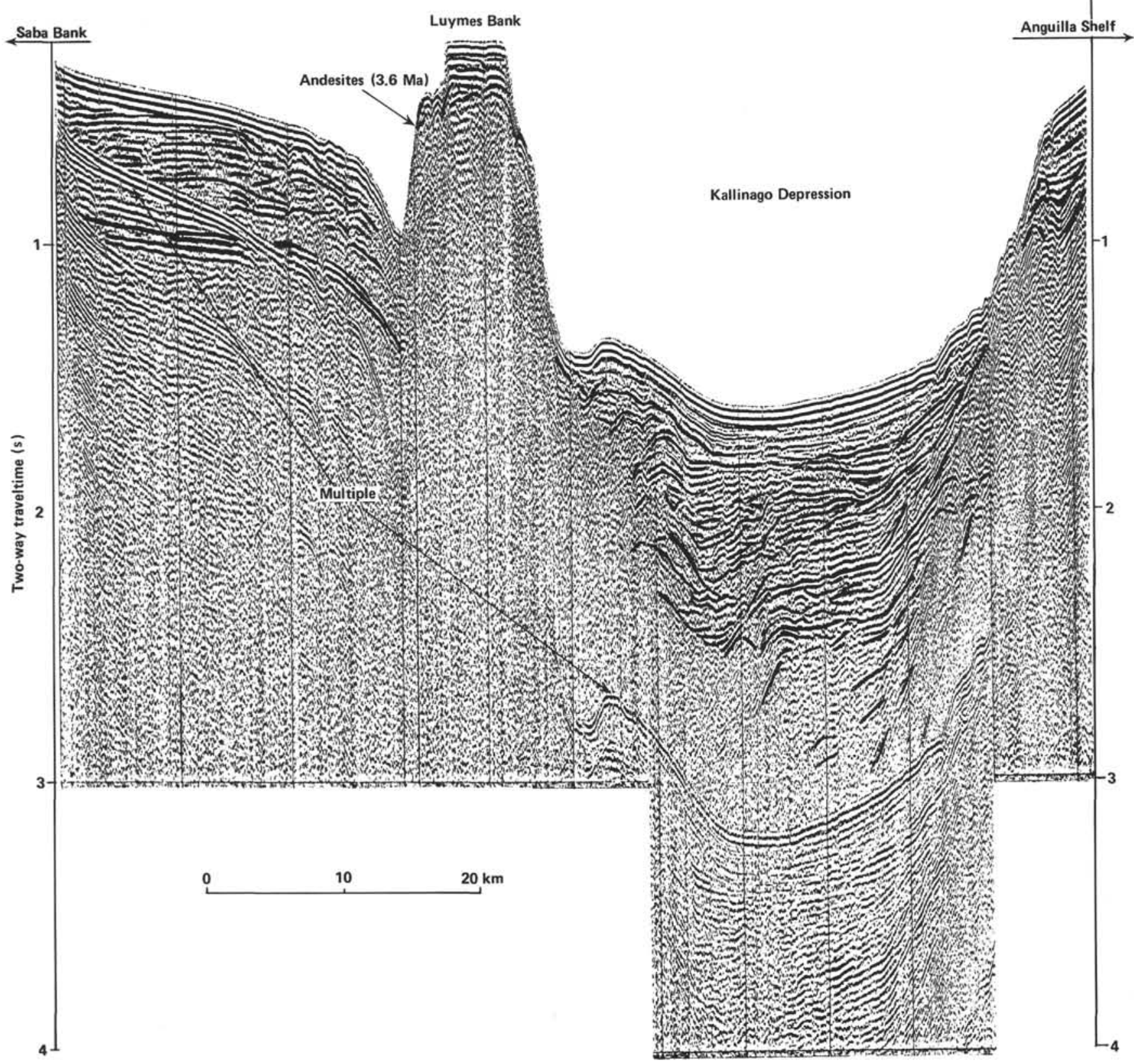

Figure 7. Water-gun seismic profile (ARCANTE 1 cruise) across Kallinago Depression (intra-arc trough) and Luymes Bank (inner arc). (The Depression is filled with about $1 \mathrm{~s}$ of Neogene sediments. Luymes Bank is a small volcanic ridge, now extinct, corresponding to the northern termination of the inner arc; on its western flank, 3.6-Ma-old andesites have been dredged. To the left, a strong sub-bottom reflector is passing through the first seabed multiple; it has been correlated with Horizon A [see Fig. 9] of Saba Bank. Some reflectors have been underlined.)

of the volcanic line from the outer to the inner arc. This event occurred in the Miocene and triggered the buildup of a western volcanic ridge. Fink (1972) suggested that the morphological gap between these two arcs could have been induced by extensional rifting related to a back-arc spreading, as demonstrated by Karig (1971) for the western Pacific area. This interpretation seems very unlikely, because the volcanic line jumped westward, away from the trench, and not toward the trench, as re- quired by the splitting process inferred from areas where back-arc spreading is well documented.

\section{Northeastern Flanks}

Between Guadeloupe and Sombrero, the eastern flanks of the Lesser Antilles Ridge have steep slopes (Figs. 1 and 3). They are made of a succession of spurs and Vshaped, flat-bottomed, reentrant valleys: Désirade, Antigua, St. Barth, and Anguilla sea troughs. The Dé- 
sirade escarpment (Fig. 8), stretching along some $70 \mathrm{~km}$ in an east-northeast direction, north and parallel to la Désirade Island, is one of the most impressive physiographic features of the world: locally it drops $4700 \mathrm{~m}$, over a horizontal distance of $9 \mathrm{~km}$ (more than $27^{\circ}$ declivity).

The Karukera Spur, striking parallel to the arc ridge axis, is perpendicular to the Désirade escarpment. It con- stitutes the easternmost part of the Lesser Antilles Ridge. It culminates at the Flandre Bank (northeast of la Désirade), whose Pliocene-Quaternary cover is underlain by "greenstones" resembling and probably structurally linked to la Désirade igneous basement. The axis of the spur deepens stepwise to the south. I feel that the Karukera Spur is the southernmost extension of a pre-Eocene basement that has not been obliterated here, as it was at

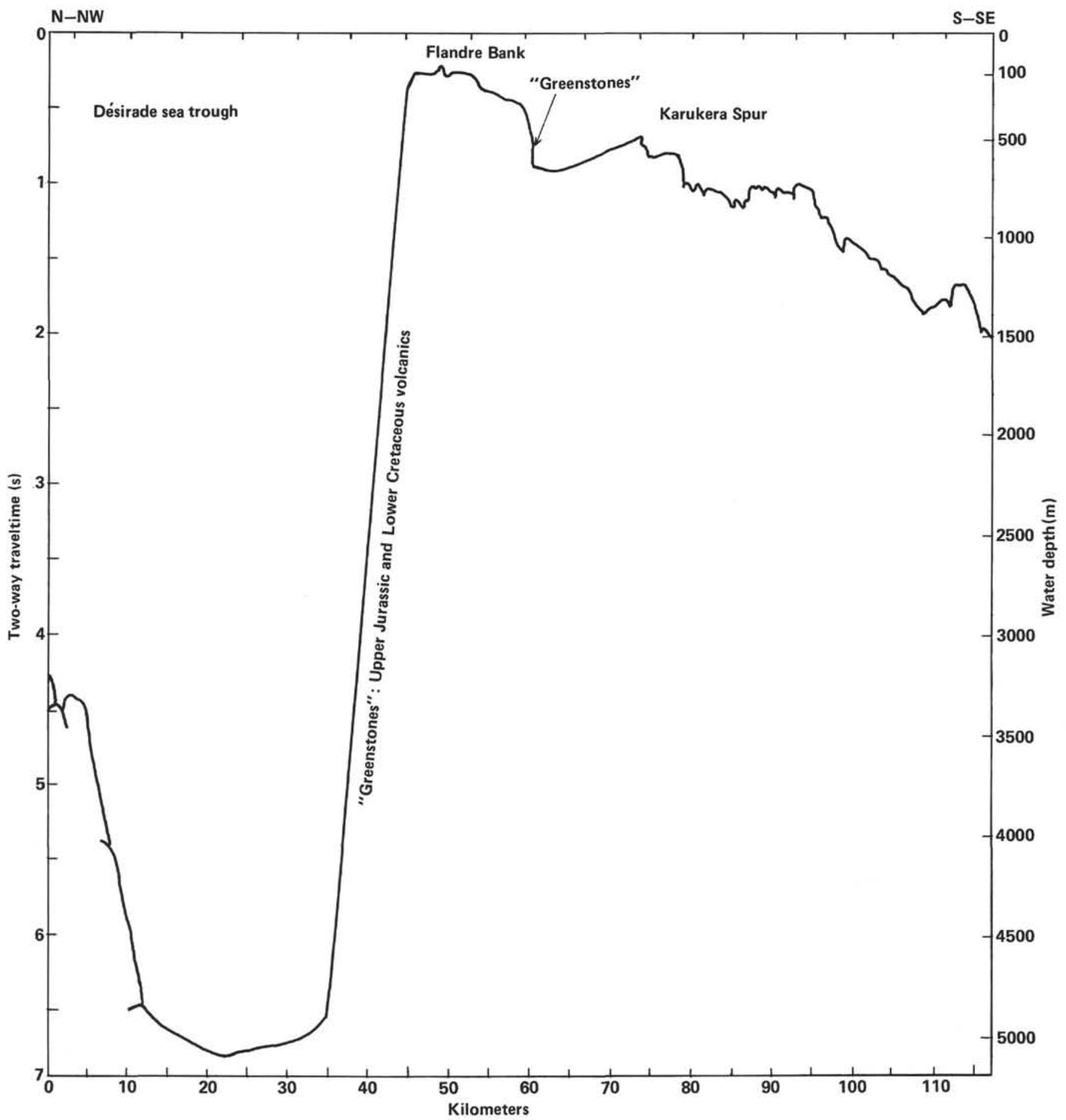

Figure 8. The Désirade escarpment, one of the steepest submarine slopes of the world. (Note the regular drop of almost $5 \mathrm{~km}$. "Greenstones" from the la Désirade Island Mesozoic igneous basement crop out all along the escarpment. Flandre Bank is the easternmost shoal of the Guadeloupe area. The morphology of Karukera Spur is rugged.) 
la Désirade, by the subsequent phases of the Cenozoic island arc magmatism.

On the slopes of these northeastern flanks, the postmiddle Miocene deposits are poorly represented; hence, older formations are exposed (Fig. 10): Upper Jurassic and Lower Cretaceous epimetamorphosed igneous rocks along the Désirade escarpment (Fig. 8) (Andreieff et al., 1979; Bouysse, Schmidt-Effing, and Westercamp, 1983); Upper Cretaceous fossiliferous volcanic tuffs eastward of Antigua and Barbuda and to the north and northeast of Anguilla (Fox and Heezen, 1975); Paleocene-Eocene neritic deposits to the north of Anguilla (Fox and Heezen, 1975); and lower Eocene and middle and upper Oligocene limestones east of Grande-Terre and southeast of Barbuda (Andreieff et al., 1979). On the Falmouth Spur (Fig. 3), extending between the Désirade and Antigua seatroughs, we have dredged a quartz-diorite that shows some similarities to the trondhjemite of la Désirade Island. Unfortunately, no significant radiogenic age could be obtained.

\section{Northwestern Flanks}

Contrasting with the northeast (Atlantic) slopes, the northwest (Caribbean) flanks are draped by a rather thick overburden of post-middle Miocene sediments (Fig. 9) (Bouysse and Guennoc, 1983). No formations older than Pliocene have been dredged to the west of the inner arc (see Andreieff et al., 1979). Recently, some Quaternary, but now extinct, submarine volcanic peaks have been discovered and/or sampled off Martinique, Basse-Terre of Guadeloupe (Anonymous, 1981; Bouysse, unpublished data: ARCANTE 1980 and 1981 cruises), and off Redonda platform (Havers Shoal, see earlier discussion).

The Saba Bank, a wide $\left(2100 \mathrm{~km}^{2}\right)$ and shallow platform (depth range: $20-40 \mathrm{~km}$ ), is located west of the northern termination of the inner arc. An exploratory well (Fig. 1), drilled in 1977 by Marathon Oil Co., supplied data of upmost importance concerning the geology of the $\operatorname{area}^{4}$ (Fig. 9). After having drilled a 2858-mthick Cenozoic sedimentary cover, the well penetrated an additional $119 \mathrm{~m}$ into porphyritic andesite, whose radiometric (K-Ar) age is $64.5 \pm 3.7 \mathrm{Ma}$, near the boundary between Paleogene and Upper Cretaceous. Marathon Oil reports that "the strongly porphyritic character could mean that the rock [andesite] was a near-surface intrusion . . . and/or part of a volcanic feeder system." The base of the igneous formation was not reached, but multichannel seismic surveys strongly suggest the presence of an extensive sedimentary section (probably Upper Cretaceous) beneath the volcanic unit. This sedimentary section could extend to a depth of some $4100 \mathrm{~m}$ below sea level. Hence, the volcanic formation did not originate as oceanic crust but was related to a regional magmatic pulse, as evidenced by nearby St. Croix Island (U.S. Virgin Islands, see Fig. 1) situated in the Anegada Passage and where the emplacement of plutonic intrusions occurred between 64 and $74 \mathrm{Ma}$ (Speed et al., 1979). Therefore, the Saba Bank appears to contain rocks of an older island arc cycle, predating the incipience (in the Eocene) of the outer volcanic arc of the Lesser Antilles. The sedimentary blanket resting unconformably on the volcanic substratum contains carbonate and clastic sequences, with some pyroclastic intercalations of upper Eocene or Oligocene to lower Miocene. The nearest micropaleontological control, made some $100 \mathrm{~m}$ above the top of the andesite, indicates lower middle Eocene (Nemec, in press).

\footnotetext{
${ }^{4}$ Unpublished information transmitted in 1979 by Mr. Clark Gomes Casseres, Saba Bank Resources N. V., Curaçao. (See: Andreieff et al., 1979; Bouysse, 1979; Bouysse, Andreieff, and Westercamp, in press; Bouysse and Guennoc, 1983; Nemec, in press.)
}

\begin{tabular}{|c|c|c|c|c|}
\hline Lithology & Pyroclastic episodes & Deposition environment & $\begin{array}{c}\text { Depth below } \\
\text { sea level }\end{array}$ & Age \\
\hline $\begin{array}{l}\text { Dominant carbonate sequence with some mudstone } \\
\text { and dolomite intercalations }\end{array}$ & A & Shelf & $23 \mathrm{~m}$ & $\begin{array}{c}\text { Recent } \\
\text { to } \\
\text { late Miocene }\end{array}$ \\
\hline $\begin{array}{l}\text { Dominant clastic sequence: mudstones, sandstones, } \\
\text { conglomerates, volcaniclastics (rare limestones) }\end{array}$ & & $\begin{array}{l}\text { Shelf } \\
\text { (fluvial influences?) }\end{array}$ & $-1168 \mathrm{~m}-$ & $\begin{array}{l}\text { early or middle } \\
\text { Miocene to } \\
\text { middle Oligocene? }\end{array}$ \\
\hline More pelitic sequence & $\hat{\imath}$ & Upper slope & $=-1555 \mathrm{~m} \cdot$ & $\begin{array}{l}\text { middle Oligocene } \\
\text { to } \\
\text { late Eocene? }\end{array}$ \\
\hline $\begin{array}{ll} & \text { Carbonate sequence } \\
\text { Transgression } & \\
\end{array}$ & $c$ & $\underbrace{\text { Shelf }}_{\text {reefal buildup }}$ & & $\begin{array}{c}\text { late Eocene } \\
\text { to } \\
\text { early middle Eocene }\end{array}$ \\
\hline Porphyritic andesite & onc & Magmatism & $-2858 m-$ & Paleocene \\
\hline $\begin{array}{l}\text { Base not reached } \\
\text { Inferred underlying sedimentary strata } \\
\text { (seismic reflection) }\end{array}$ & & & $-291 / \mathrm{m}-$ & Late Cretaceous \\
\hline
\end{tabular}

Figure 9. Summary of exploratory Well SB1 drilled on Saba Bank by Marathon Oil Co. in 1977. (Location: $17^{\circ} 17^{\prime} 22^{\prime \prime} \mathrm{N}$ and $63^{\circ} 25^{\prime} 34^{\prime \prime} \mathrm{W}$; water depth: $23 \mathrm{~m}$. Information kindly transmitted in 1979 by Mr. C. Gomes Casseres [Saba Bank Resources N.V., Curaçao]. 


\section{Active Submarine Volcanism}

In the Catalogue of the Active Volcanoes of the World. Part XX: West Indies (Robson and Tomblin, 1966), three active submarine volcanoes are noted: from south to north, the "Kick'em Jenny" (No. 16-16) north of Grenada, "Hodder's Volcano" (No. 16-13) west of St. Lucia, and a "submarine volcano near Marie-Galante" (No. 16-7).

In reality the Kick'em Jenny is the only submarine volcanic edifice in activity in the Lesser Antilles. It is a volcanic cone, built-up on the western slope of the South Grenadines Bank, and made of amphibole-bearing basalts (Sigurdsson and Sheperd, 1974). The first recorded eruption occurred in 1939 and, up to now (late 1982), 8 other presumed outbursts (1943 to 1977) have taken place; only 2 of them have been observed directly on the surface, in 1939 and 1974 . The former crater, still extant in 1972, disappeared after the last 1977 outburst. The volcano is growing regularly and its top is now $160 \mathrm{~m}$ below sealevel (Sigurdsson and Sparks, 1979; Bouysse, unpublished data; ARCANTE 3 cruise, 1981).

Thanks to a Seabeam (multibeam echo-sounder computerized system) survey, carried out in December 1980 (ARCANTE 2 cruise), it can be asserted that the Hodder volcano does not exist. Its reported existence was based on two discolored seawater patches observed on 9 May 1902 by Major Hodder west of Castries, St. Lucia (Anderson and Flett, 1903). At the site of this event, no volcanic structure is to be observed. In my opinion, this phenomenon was due to recurrent faulting triggered by the dramatic volcano-seismic crisis of May 1902, which provoked the concomitant eruptions of Montagne Pelée in Martinique and of the Soufrière of St. Vincent (Bouysse, 1982; Bouysse and Sigurdsson, 1982).

The water column surging observed by Blainville in 1843 between Basse-Terre of Guadeloupe and MarieGalante was in reality a submarine geyser spouting from the Colombie Bank (Bouysse, 1980). This seamount is not a volcano but a small submarine bank covered with a continuous sedimentary cover, at least $100 \mathrm{~m}$ thick. The water outburst is related to a series of violent earthquakes, which was one of the most destructive in the history of the Lesser Antilles (magnitude >8; Dorel, 1981).

\section{General Organization of the Lesser Antilles and the Problem of the Aves Swell}

By considering the general features and the morphological pattern of the Lesser Antilles (Fig. 10), I was led to conclude (Bouysse, 1979) that there is a sharp contrast between the northern and southern parts of the archipelago. One of the most striking observations is that the $1000-\mathrm{m}$ isobath encircles two areas separated by a depression that runs between Martinique and Dominica. Each part corresponds to about half $(425 \mathrm{~km})$ of the total curvilinear length of the Lesser Antilles ridge. The northern area is three times larger than the southern one: $50,300 \mathrm{~km}^{2}$ versus $16,600 \mathrm{~km}^{2}$. This discrepancy reflects, to my mind, a major difference of origin between the northern and southern Lesser Antilles. The major axis of discontinuity runs, sublatitudinally, from the north of Aves Swell to the north of Grenada Basin, the south of Guadeloupe archipelago, and between the southern end of Puerto Rico Trench and the northern border of Barbados accretionary prism. This observation has been documented in a previous paper (Bouysse, 1979) independently of the assumption of Meyerhoff and Meyerhoff (1972), which it corroborates, postulating an inactive "Dominica fault."

In the nothern part of the Lesser Antilles, the wide space occupied by the island arc ridge coincides with the occurrence of a Mesozoic substratum reported, up to now, at Saba Bank, la Désirade, and along the north and northeast flanks of the Lesser Antilles. In the southern part, the volcanic basement is rather narrow, with the oldest island arc formations not older than lower or middle Eocene. For that reason, I think that the substratum of the northern Lesser Antilles belongs to an ancient arc related to the Greater Antilles, which were an active island arc during the Mesozoic (see, for example, Donnelly, 1975), whereas the southern part, from Dominica or Martinique, is younger and was initiated, as an island arc, only in the Eocene.

As stated by Case (1975), a pronounced high of the gravity field (see also Weeks et al., 1971; Bowin, 1976) extends from the Lesser Antilles through Los Testigos to Margarita, both islands being located on the Venezuelan continental shelf. The anomalies (Bouguer and isostatic anomalies) overlie metamorphosed Mesozoic rocks and ultramafics at Margarita. Nevertheless, I do not feel that this main geophysical feature necessarily implies the continuity of a Mesozoic basement from the Greater Antilles to the Venezuelan borderland, through the entire length of the Lesser Antilles. This positive geophysical axis might be ascribed to other causative processes: why not to a later (Eocene?) orogenic pulse? In any case, Nagle (1971) noted that it is very uncertain what happens to the Lesser Antilles structural trend south of Grenada. From isostatic anomaly data, it is evident that the Lesser Antilles are not in isostatic equilibrium, and considerable excess mass is present beneath the islands (Case, 1975).

Aves Swell (or Ridge) and Grenada Basin have raised debate regarding their relations with the Lesser Antilles island arc and, more generally, with the subduction process acting at the eastern boundary of the Caribbean Plate.

The morphological pattern of Aves Swell seems to indicate that its northern termination passes not far from Aves Islet (Fig. 1), and not at the junction of the Greater and the Lesser Antilles, as stated by Fox and Heezen (1975). The Aves Swell has long been an enigma to Caribbean geologists (Donnelly, 1975), but there is now a broad agreement considering this Ridge as an ancient island arc structure (Bunce et al., 1970; Weeks et al., 1971; Nagle, 1972; Keary, 1974 and 1976; Donnelly, 1975; Fox and Heezen, 1975; Keary et al., 1975; Westbrook, 1975; Biju-Duval et al., 1978; Clark et al., 1978). The Aves Swell, breaking the sea surface only at tiny Aves Island (made of Quaternary reefal limestones and sands), is aseismic (Weeks et al., 1971). It is formed by 


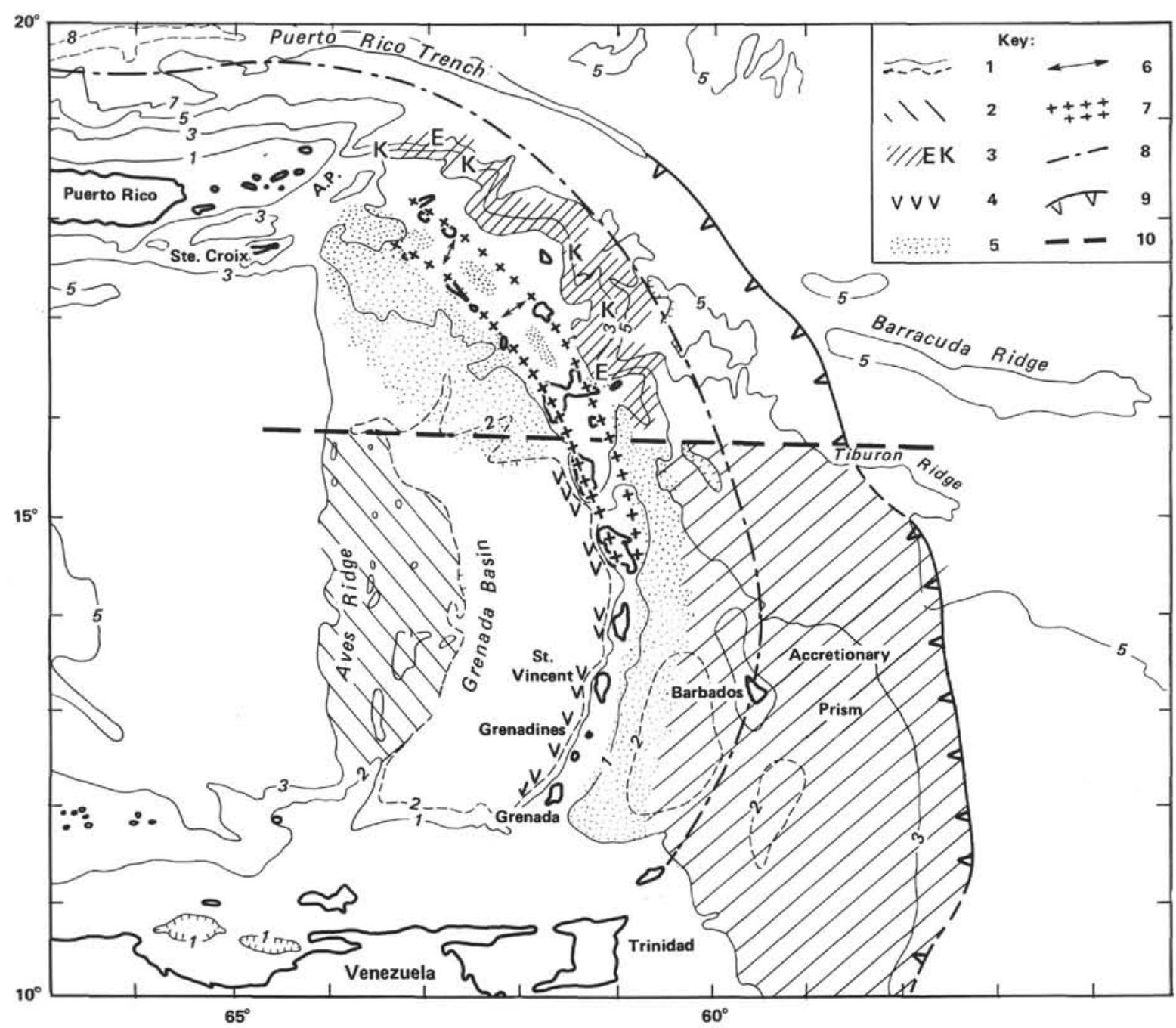

Figure 10. Schematic morphostructural setting showing the contrast between the northern and southern parts of the Lesser Antilles Ridge and neighboring areas. (Key: $1=$ isobaths in kilometers; $2=$ insular shelves and submarine banks; $3=$ steep NE flanks with outcrop of Eocene (E) and Upper Cretaceous (K) formations; 4 = steep western slopes of the southern Lesser Antilles Ridge; $5=$ thick recent sedimentation on the Ridge flanks; $6=$ Kallinago transverse swells; $7=$ inner and outer arcs axis; 8 = axis of negative gravity anomaly (after Bowin, 1976); 9 = overriding deformation front; and $10=$ line separating northern and southern provinces.)

two flanking ridges of volcanic origin, enclosing a central, sediment filled, trough (Keary, 1976). Like the Lesser Antilles, the Aves Swell displays a short-wavelength, high-amplitude magnetic anomaly pattern typical of features created by magmatic processes (Keary et al., 1975; Clark et al., 1978). Dredging carried out on the slopes of protruding seamounts brought up sedimentary and volcanic rocks, and locally to the south (not far from the Venezuelan margin), granodiorites and diabases (Fox et al., 1971; Nagle, 1972; Fox and Heezen, 1975). Three samples of the granodioritic intrusions, somewhat weathered, provided $\mathrm{K}-\mathrm{Ar}$ ages of respectively 78 and $89 \mathrm{Ma}$ (lower Senonian), 65 and $67 \mathrm{Ma}$ (upper limit of Senonian), and 57 and $58 \mathrm{Ma}$ (upper Paleocene). The ages obtained for the diabase are 57 and 60 Ma. Fox and co-workers $(1971,1975)$ noted that the granitic rocks may represent the northern edge of the South American platform, but they suggested that the Aves Swell is underlain by granitic crust derived from oceanic material. Petrological studies (Walker et al., 1972) indicated that the granitic rocks are primitive and most likely from upper mantle. It is now established (Lameyre and Bowden, 1982) that granitoid series do not necessarily imply that they are related to continental crust processes; the granodiorites are the plutonic expression of island arc or active margin calc-alkaline suites. Furthermore, same types of rocks, but of the Oligocene, occur in the Lesser Antilles at St. Martin and St. Bartholomew (Christman, 1953; Nagle et al., 1976; Westercamp and Andreieff, in press). The other igneous rocks (effusive volcanics) have not been dated, but it seems that they are capped by post-Paleocene sedimentary formations (Nagle, 1972; Fox and Heezen, 1975). The Eocene to lower Miocene neritic limestones were followed by mid-Miocene to Holocene pelagic sedimentation. DSDP Hole 30 (Fig. 1) bottomed in middle Miocene, after $430 \mathrm{~m}$ of penetration in pelagic ooze (Shipboard Scientific Party, 1970); DSDP Hole 148 penetrated only 
$272 \mathrm{~m}$ of sediments represented by Pliocene-Quaternary pelagic ooze resting unconformably on volcanic sands containing lower Miocene, Paleocene, and Upper Cretaceous microfauna (Shipboard Scientific Party, 1973).

The K-Ar ages, if they are fully reliable, reflect magmatic activity from Late Cretaceous to Paleocene. The shallow-water environment, subsequent to the cessation of the volcanic activity, induced the formation of carbonate platforms built over the volcanic pedestals, such as later took place in the northeast part of the Lesser Antilles. The persistence, and probably the increase of the subsidence, led to a lowering of some $1000 \mathrm{~m}$ and to a complete submersion of the ridge (Aves Islet excepted). As for the Lesser Antilles arc, seismic refraction data show that the crust thickens notably beneath the Aves Swell (Tomblin, 1975). The crust is nearly in isostatic balance (slightly negative), judged from the values of isostatic anomalies (Keary, 1974; Case, 1975). Heat-flow measurements made along a section joining the Venezuelan Basin to the east of the Lesser Antilles agree with an island arc formation for the Aves Swell, with high values attributed to radiogenic sources concentrated during subduction in the past (Clark et al., 1978).

From the present data, it is difficult to determine the polarity of the former Wadati-Benioff zone beneath the Aves Swell. Donnelly (1975) seems to favor a subduction zone dipping from the west, although it is commonly assumed that the polarity was the same as that of the present Lesser Antilles (see, for example, Tomblin, 1975). I would be inclined to agree with a subducting slab plunging from the east of Aves Swell, mainly because of the arcuate nature of the eastern flank of the ridge.

It has been suggested that the Aves Swell may have represented a remnant arc (third arc) such as Karig (1971, 1972 , 1974) has proposed for some of the West Pacific island arcs, and that, consequently, the Grenada Basin might have been created by an active marginal basin spreading. An alternate possibility is that the Grenada Basin was a trapped basin when the locus of the underthrusting of the Atlantic crust stepped back-probably in early Eocene-from the Aves Swell to its present position underneath the southern Lesser Antilles.

The first hypothesis was mentioned or supported by Donnelly (1975), Westbrook (1975), Shurbet (1976), Boynton et al. (1979), Uyeda and Kanamori (1979), and Uyeda (1982). The second hypothesis was favored by Freeland and Dietz (1971) and Keary (1976). For other authors, the present state of knowledge is inconclusive as to make a choice between the two possibilities (Nagle, 1972; Keary, 1974; Tomblin, 1975). If we use the terminology of Uyeda and Kanamori (1979), our alternative is between an inactivated and a trapped back-arc basin. If Aves Swell really split off from the Lesser Antilles Ridge, the onset of the westward relative drift should have occurred in late Paleocene or early Eocene. Consequently, the crust of Grenada Basin should not be older than Eocene. On the other hand, the back-arc spreading should have ceased a long time ago, because Grenada Basin is filled, as established earlier in this chapter, by several kilometers of sediments. Furthermore, there are no remnant higher heat-flow values inside this Basin
(Clark et al., 1978) marking the trace of an older midbasin accretionary volcanic ridge. Besides, numerous multichannel seismic profiles, run for oil exploration, did not reveal any concealed remnant topographic high of the basement underneath the sedimentary cover of the Grenada Basin (A. Mascle, personal communication, 1982). The Grenada Basin is also characterized by lack of organized magnetic anomalies (see for example, Keary et al., 1975). Although not generalized and less distinct than "normal" accreted oceanic crust, magnetic anomalies have been identified in a number of presently or formerly active marginal basins (Molnar and Atwater, 1978; Jurdy, 1979). But the most important point is the absence of a common origin for the igneous basement of the Aves Swell (pre-Eocene) and its supposed counterpart (as required by Karig's model), the southern half of the Lesser Antilles (post-Paleocene).

For all these reasons, I assume that the Grenada Basin is a trapped back-arc basin and, hence, that the Aves Swell is the predecessor of the southern Lesser Antilles.

\section{GEODYNAMIC EVOLUTION}

The data just presented allow us to propose a very schematic and speculative evolutionary scenario for the eastern border of the Caribbean Plate (Bouysse, 1979; Bouysse, Andreieff, and Westercamp, in press). The question of subduction polarity in the Greater Antilles during the Mesozoic and early Cenozoic remains elusive and is doubtless complex (see Donnelly, 1975). Nevertheless, in order to address it, and despite the fact that knowledge of the geodynamic evolution of the Greater Antilles is so incomplete, I have taken into account the suggestions of Mattson (Mattson, 1979; Mattson and Pessagno, 1979).

Stage 1 (Fig. 11A). Near the end of the Jurassic, the northern Antilles were connected to the Greater Antilles active island arc, with a subduction zone possible plunging toward the north. This stage may have lasted from Oxfordian (?) to Early Cretaceous (ca. 150 to ca. 110 $\mathrm{Ma}$ ).

Stage 2 (Fig. 11B). This stage lasted from Aptian to the beginning of Eocene (ca. 110 to ca. $50 \mathrm{Ma}$ ). The subduction polarity flipped, dipping to the south in the Greater Antilles. However, in the western Greater Antilles, the subduction ended earlier (about $85 \mathrm{Ma}$, Santonian). Beyond the Guadeloupe archipelago, the WadatiBenioff zone extended, possibly offset by a transform fault, to the south where it generated the Aves Ridge island arc. During this time, the buildup of the northern Lesser Antilles basement was completed, whereas to the south of Guadeloupe, oceanic crust was present east of the Aves Swell.

Stage 3 (Fig. 11C). From Eocene (early? or middle?) to late Oligocene (or possibly early Miocene), the former pattern no longer existed. Subduction ceased in the Greater Antilles and under Aves Swell. In the eastern Greater Antilles, the eastward retreat of the volcanic activity possibly overlapped the end of stage 2 and the beginning of stage 3 . This is documented by the latest island arc eruptive activity, which occurred during early and middle Eocene in easternmost Cuba, east Jamaica, 


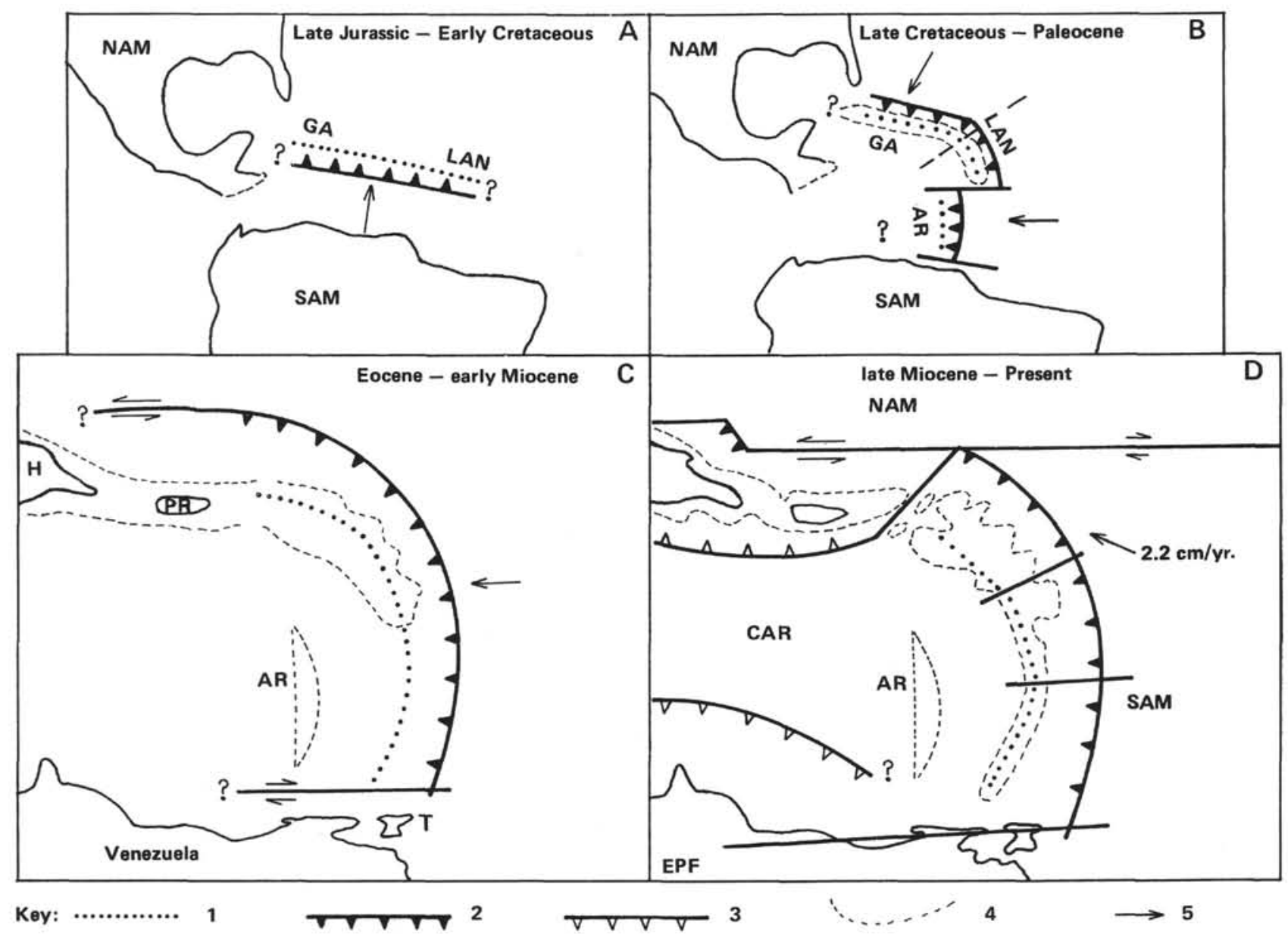

Figure 11. A-D. Evolutionary scenario proposed for the Lesser Antilles island arc from Mesozoic to Present discussed in the text. (Key: $1=$ active volcanic line [note the Present tripartite segmentation of this line in Fig. 11D]; $2=$ subduction zone; $3=$ incipient subduction zone in Fig. 11D [Los Muertos Trench to the north; foot of Curaçao Ridge to the south; after Mascle et al., 1977]; $4=$ island arc basement built up during the former stage(s); $5=$ general orientation of the subduction vector. GA $=$ Greater Antilles; LAN = northern Lesser Antilles; AR = Aves Ridge; CAR, NAM, and SAM = Caribbean, North America and South America plates (after Dorel, 1978); $\mathrm{H}=$ Hispaniola; P.R. = Puerto Rico; $\mathrm{T}=$ Trinidad; EPF $=$ El Pilar fault.

Hispaniola, and Puerto Rico (Mattson and Pessagno, 1971; Cox et al, 1977). The ultimate stage of plutonic activity was recorded in Puerto Rico between 38 and 46 $\mathrm{Ma}$ (middle to late Eocene) and at the eastern tip of the Greater Antilles-in the Virgin Island where the Virgin Gorda batholith yielded an age of about $35 \mathrm{Ma}$ (Cox et al., 1977), that is, the Eocene/Oligocene boundary. For the first time, subduction occurred along the entire length of the present Lesser Antilles. The eastward jump of the southern subduction zone generated the Grenada Basin by trapping the oceanic crust between Aves Ridge and the southern Lesser Antilles. During this third stage, the narrow Lesser Antilles outer arc was active and was superimposed, in the northern half, on the Mesozoic island arc basement.

This major rearrangement in the Caribbean, from the onset of the Eocene, might be linked with planetary plate reorganizations triggered by the Tethyan collisions occurring around 40 to $55 \mathrm{Ma}$ (Rona and Richardson, 1978).

Stage 4 (Fig. 11D). From Grenada to St. Lucia, the former subduction process persisted unmodified from the Miocene until Present, which explains the narrowness of the related insular ridge. In the central part of the Lesser Antilles, the volcanic axis shifted progressively across a zone of moderate width, from the outer arc emplacement to its present position, producing an intermediate arc. This arc is particularly obvious in Martinique (Andreieff et al., 1976; Westercamp, 1977 and 1979; Gérard et al., 1981) and may have also occurred in the Guadeloupe archipelago, as suggested by the morphological setting. But it is still a matter of speculation because of the lack of sufficient deep drill holes through the sedimentary cover that masks the volcanic substratum of Grande-Terre of Guadeloupe.

In the northern third of the Lesser Antilles (see Fig. $12)$, the volcanic line jumped from the outer arc to the inner arc after a time gap of some 10 to $20 \mathrm{Ma}$ (cessation of activity during the upper Oligocene or early Miocene; renewal during the late Miocene). This jump could have been initiated by the arrival, in the subduction zone, of the western extremity of the Barracuda Ridge. This segment is thought to be presently located under the Lesser Antilles, in the area of Antigua (Marlow 


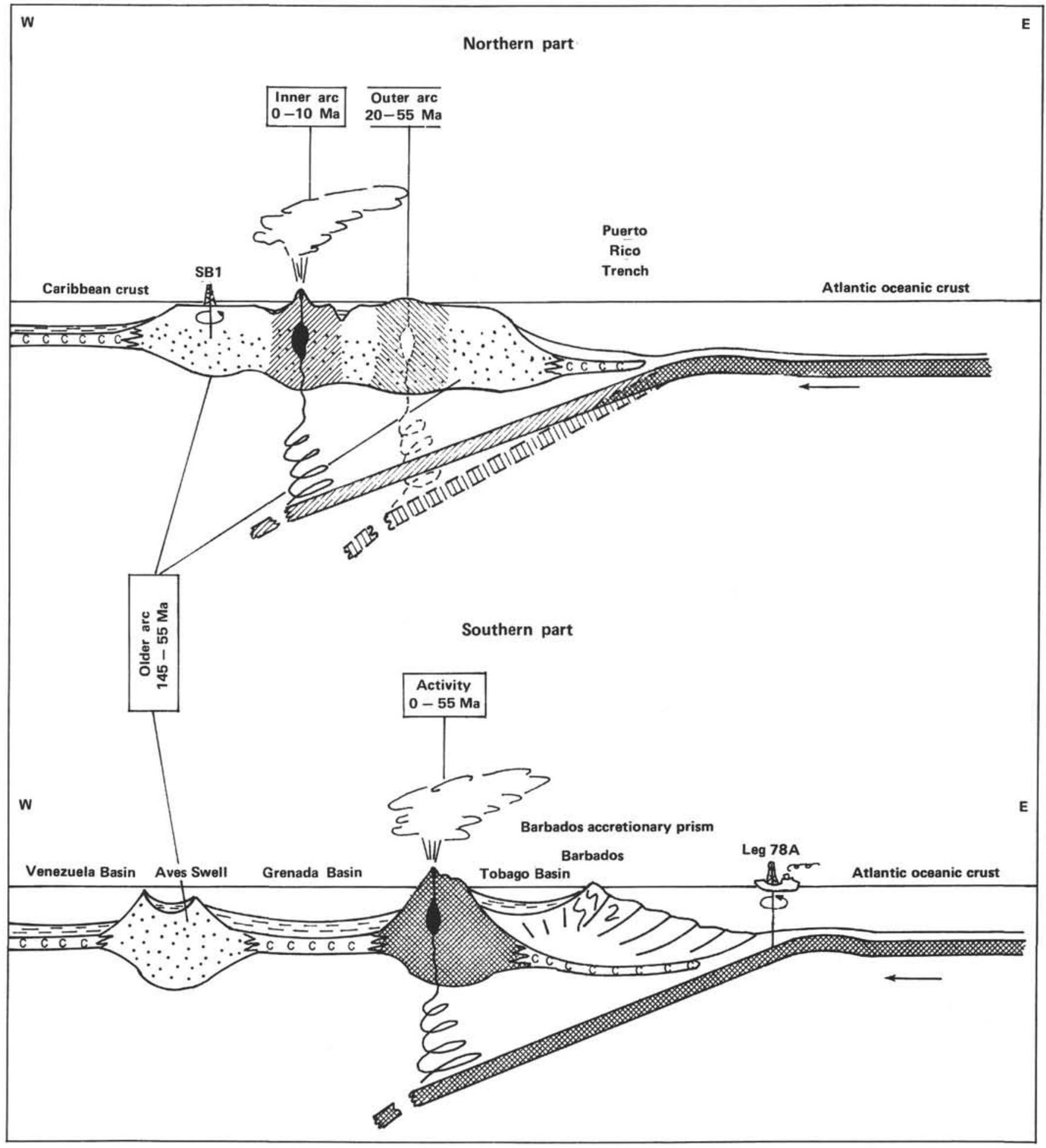

Figure 12. Interpretative schematic sections across the northern and southern Lesser Antilles Ridge. (In the northern part, the subduction process is assumed to have been interrupted between 20 and $10 \mathrm{Ma}$, possibly due to the arrival of the western tip of Barracuda Ridge in the subduction trench; consequently the volcanic activity jumped from the outer to the inner arc. Both arcs were superimposed on an older island arc basement related to the Greater Antilles and to Aves Swell. In the southern part, the subduction geometry remained unchanged from Eocene. SB1 = Saba Bank exploratory well. Caribbean crust is represented by C). 
et al., 1974; Peter and Westbrook, 1976; McCann and Sykes, 1981). The Barracuda Ridge is an aseismic but not buoyant (Bowin, in press) oceanic ridge, associated with Atlantic fracture zones. Consequently, I suggest that this interaction was accommodated by a modification of the geometry of the subduction and, possibly, by a momentary interruption of the progression of the plunging slab. In any case, because of the density of the Ridge, the subduction resumed with a slightly modified angle of dip. When the tip of the slab again reached critical depth (about $100 \mathrm{~km}$ ), volcanism was reactivated and initiated the present inner arc. Between Guadeloupe and Martinique, the effect on the progression of the subducting slab was attenuated and only a progressive shift of the volcanic line is observed, decreasing gradually to the south. South of Martinique, the subduction was not affected.

\section{ABOUT THE MAGMATIC ACTIVITY OF THE LESSER ANTILLES ISLAND ARC}

In this chapter, I shall not dwell on magmatic evolution and characterization of the Lesser Antilles. The interested reader is requested to refer to the general publications of Tomblin (1975), Gunn and Roobol (1976), Brown et al. (1977), Donnelly and Rogers (1978, 1980), Westercamp (1979), and Smith et al. (1980). I shall only briefly mention some general statements. According to mineralogical assemblages, petrochemistry, geochemistry, relative chronology and tectonic setting, five rock series are distinguished (Westercamp, 1979): (1) tholeiitic series (first stage, mainly submarine); (2) primary calc-alkaline series; (3) secondary calc-alkaline series; (4) olivine-rich subalkaline basalt series (occurring along transverse faults, probably bounding lithospheric blocks); and (5) alkaline series (exclusively located at the southern end of the archipelago-Grenadines and Grenada). It seems that the temporal succession of the first three series characterizes the complete evolution of an island arc section limited in time and space. For example, this succession occurred during the very short magmatic cycle ( 2 or $3 \mathrm{Ma}$, in the middle Eocene) of St. Barth, as demonstrated by Westercamp and Andreieff (in press). As stressed by Smith et al. (1980), piecing together a model of the magmatic variation and plate mechanism for the Lesser Antilles is still a highly speculative exercise, because for most islands the chemistry and ages of the different volcanic centers are not known.

If one considers the Lesser Antilles arc as a whole, one can see that it was volcanically active, without major interruptions, from Late Jurassic to Present. For this purpose I have plotted on Figure 13 all the evidence of magmatic activity known to us until now: morphological evidence (for recent volcanoes), K-Ar dates, fossiliferous intercalations in volcanic formations, pyroclastic tuffs (Christman, 1953, 1972; Westermann and Kiel, 1961; Robson and Tomblin, 1966; Baker, 1969, 1981; Martin-Kaye, 1969; Robinson and Jung, 1972; Mattinson et al., 1973, 1980; Javet and Alsac, 1974; Sigurdsson and Shepherd, 1974; Andreieff et al., 1976; Arculus, 1976; Nagle et al., 1976; Westercamp and Mervoyer, 1976; Andreieff et al., 1979; Baubron et al., 1979; Bri- den et al., 1979; Frost and Weiss, 1979; Andreieff et al., 1981; Jackson, 1980; Andreieff et al., in press; Bouysse, Schmidt-Effing, and Westercamp, 1983; Westercamp and Andreieff, in press; Bureau de Recherches Géologiques et Minières (BRGM) unpublished data). The tuffs, of course, do not necessarily indicate that the relevant eruption has taken place in situ but elsewhere in the neighborhood of their occurrence. This provisional inventory provides limited information because it only documents the existence of the studied outcrops of the Lesser Antilles Ridge (Saba Bank excepted). Nevertheless it might provide a guide to the investigation of volcanic ashes interspersed in cores from sites drilled during Leg $78 \mathrm{~A}$ or perhaps to be drilled in the sedimentary basins of the eastern Caribbean.

In a recent paper, Sigurdsson et al. (1980) studied the problem of late Quarternary volcanogenic sedimentation in the Lesser Antilles arc and came to very interesting conclusions. For the last 10,000 yr., over $80 \%$ of the total volcanic bulk produced in the Lesser Antilles arc has been deposited as volcanogenic sediments in the adjacent marine basins. There is a high asymmetry in the distribution of volcanogenic sediments around the arc. Over $70 \%$ of the total volcanogenic sedimentation from the arc is supplied to the Grenada Basin in the form of sediment gravity flows. Conversely, ash-fall layers prevail in the Atlantic. This east-west opposition is due to the contrasting effects of prevailing high altitude wind direction (westerlies, above $\mathrm{km}$ altitude) and different submarine arc slope physiography (steep western slopes versus gentler and irregular eastern slopes) and ocean currents (westward prevailing current transportation).

\section{ACKNOWLEDGMENTS}

I would like to express special thanks to my companions Patrick Andreieff and Denis Westercamp (BRGM) who work closely with me on the ARCANTE project. I am also grateful to my other colleagues who have taken part in land-based surveys, marine geology cruises, analytical work, or data interpretation, particularly René-Charles Maury (Université de Bretagne Occidentale), Alain Mascle (Institut Français du Pétrole), Raymond Le Suavé and Serge Robert (Centre Océanologique de Bretagne), Jean-Claude Baubron and Pol Guennoc (BRGM). I extend my thanks to the officers and crews of the ARCANTE 1, 2, and 3 cruises for their helpful cooperation. I am also indebted to Mr. Clark Gomes Casseres (Saba Bank Resources N.V., Curaçao) and to Dr. Jean-Guy Schilling (University of Rhode Island) who kindly put some unpublished data on submarine samples at our disposal. I have also benefitted from critical reviews of the manuscript by Dr. James E. Case and Dr. Eli A. Silver.

\section{REFERENCES}

Anderson, T., and Flett, J. S., 1903. Report on the eruptions of the Soufrière in St. Vincent, in 1902, and on a visit to Montagne Pelée, in Martinique. Part I.Philos. Trans. Ry. Soc. London, Ser. A, 200: 353-553.

Andreieff, P., 1982. Stratigraphie et micropaléontologie des formations sédimentaires des îles du plateau insulaire d'Anguilla-St. Barthélémy (Petites Antilles). Résum. Ppaux. Résult. Sci. Technol. Serv. Géol. Nat., Bur. Rech. Géol. Min. France, 58.

Andreieff, P., Bellon, H., and Westercamp, D., 1976. Chronométrie et stratigraphie comparée des édifices volcaniques et formations sédimentaires de la Martinique (Antilles françaises). Trans. 7th Conf. Géol. Caraibes Guadeloupe, 1974), 345-356.

Andreieff, P., Bizon, G., and Bouysse, P., 1981. Révision de l'âge des formations sédimentaires de l'île de St. Martin: Implications sur la chronologie du volcanisme de l'arc insulaire des Petites Antilles. C. R. Acad. Sci., France, Sér. II, 292:79-82. 
Andreieff, P., Bouysse, P., and Westercamp, D., 1979. Reconnaissance géologique de l'arc insulaire des Petites Antilles, Résultats d'une campagne à la mer de prélèvements de roches entre Ste Lucie et Anguilla (ARCANTE I). Bull. Bur. Rech. Géol. Min. France, Sér. IV, 227-270.

in press. Révision de la géologie de l'île de Marie-Galante (Petites Antilles). Bull. Soc. Géol. France.

Andreieff, P., and Cottez, S., 1976. Sur l'âge, la structure et la formation des îles de Grande-Terre et de Marie-Galante (Guadeloupe, F.W.I.). Trans. 7th Conf. Géol. Caraîbes (Guadeloupe, 1974), 229-233.

Anonymous, 1981. Des volcans sous-marins anciens au large de la Guadeloupe. La Recherche France, 12(123):734.

Arculus, R. J., 1976. Geology and geochemistry of the alkali basaltandesite association of Grenada, Lesser Antilles island arc. Geol. Soc. Am. Bull., 87:612-624.

Baker, P. E., 1969. The geological history of Mount-Misery volcano, St. Kitts, West Indies. Overseas Geol. Mineral. Resour., G.B., 10(3): 207-230.

1981. Geology and geochemistry of the Mansion pyroclastic fall succession, St. Kitts. Bull. Volcanol., 43-2:303-310.

Baubron, J. C., Bouysse, P., Maury, R. C., and Westercamp, D., 1979. L'îlot Redonda, un jalon de l'arc volcanique récent des Petites Antilles. Bull. Bur. Rech. Géol. Min. France, Sér. IV, 273-283.

Biju-Duval, B., Mascle, A., Montadert, L., and Wanneson, J., 1978. Seismic investigations in the Colombia, Venezuela and Grenada basins, and on the Barbados Ridge for future IPOD drilling. Geol. Mijnbouw, 57(2):105-116.

Blainville, C. de, 1843. Sur un volcan qui a fait éruption entre la Guadeloupe et Marie-Galante. C.R. Acad. Sci. Paris, 16(19): 142-143.

Bouysse, P., 1979. Caractères morphostructuraux et évolution géodynamique de l'arc insulaire des Petites Antilles (campagne ARCANTE 1). Bull. Bur. Rech. Géol. Min. France, sér. IV, 3/4:185-210.

1980. Sur l'existence d'un volcan sous-marin dans l'archipel de la Guadeloupe. Commentaires sur le problème du volcanisme sous-marin historique dans l'arc insulaire des Petites Antilles. Bull. Bur. Rech. Géol. Min. France, Sér. IV, no. 1, p. 3-14.

1982. Réfutation de l'existence d'un volcan sous-marin actif sur la zone "Hodder," au large de Ste-Lucie, Petites Antilles. Résum. Ppaux. Résult. Sci. Technol. Serv. Géol. Nat., Bur. Rech. Géol. Min. France, 70-71.

Bouysse, P., Andreieff, P., and Westercamp, D., in press. Evolution of the Lesser Antilles island arc, new data from submarine gology. Trans. 9th Caribbean Geol. Conf. (Santo Domingo, 1980).

Bouysse, P., and Guennoc, P., 1983. Données sur la structure de l'arc insulaire des Petites Antilles, entre St. Lucie et Anguilla. Mar. Geol., 53:131-166.

Bouysse, P., Maury, R. C., Westercamp, D., and Baubron, J. C., 1981. Le banc Luymes, terminaison septentrionale de l'arc récent des Petites Antilles. Bull. Soc. Géol. France, 23(2):185-194.

Bouysse, P., Schmidt-Effing, R., and Westercamp, D., 1983. La Désirade Island (Lesser Antilles) revisited: Lower Cretaceous radiolarian cherts and arguments against an ophiolitic origin for the basal complex, Geology, 11:244-247.

Bouysse, P., and Sigurdsson, H., 1982. The "Hodder phenomenum" of 1902: no active submarine volcano off St. Lucia (Lesser Antilles). Mar. Geol., 50(1/2):M29-M36.

Bowin, C., 1976. Caribbean gravity field and plate tectonics. Geol. Soc. Am. Spec. Pap., 169:1-79.

in press. Gravity and geoid anomalies of the Caribbean. Trans. 9th Caribbean Geol. Conf. (Santo Domingo, 1980).

Boynton, C. H., Westbrook, G. K., Bott, M. H. P., and Long, R. E., 1979. A seismic refraction investigation of crustal structure beneath the Lesser Antilles island arc. Geophys. J. R. Astron. Soc. London, 58:371-393.

Briden, J. C., Rex, D. C., Faller, A. M., and Tomblin, J. F., 1979. KAr geochronology and paleomagnetism of volcanic rocks in the Lesser Antilles arc. Philos. Trans. Ry. Soc. London, 291(A1383): 485-528.

Brown, G. M., Holland, J. G., Sigurdsson, H., Tomblin, J. E., and Arculus, R. J., 1977. Geochemistry of the Lesser Antilles volcanic island arc. Geochim. Cosmochim. Acta, 41:785-801.
Bunce, E. T., Phillips, J. D., Chase, R. L., and Bowin, C. O., 1970. The Lesser Antilles arc and the eastern margin of the Caribbean Sea. In Maxwell, A. E. (Ed.), The Sea (Vol. 4): New York (WileyInterscience), 359-385.

Burke, K., Fox, P. J., and Sengor, A. M. C., 1978. Buoyant ocean floor and the evolution of the Caribbean. J. Geophys. Res., 83(B8): 3949-3954.

Butterlin, J., 1977. Géologie Structurale de la Région des Caraibes. Paris (Masson éd.)

Case, J. E., 1975. Geophysical studies of the Caribbean Sea. In Nairn, A. E. M., and Stehli, F. G. (Eds.), The Ocean Basins and Margins (Vol. 3): New York (Plenum Press), 663-689.

Case, J. E., and Holcombe, T. L., 1980. Geologic-tectonic map of the Caribbean region. U.S. Geol. Surv., Misc. Invest., Map I-1100, scale $1 / 2,500,000$.

Christman, R. A., 1953. Geology of St. Bartholomew, St. Martin, and Anguilla, lesser Antilles. Geol. Soc. Am. Bull., 64:65-96. 1972. Volcanic geology of southwestern Antigua, B.W.I. Geol. Soc. Am., Mem., 132:439-448.

Clark, T. F., Korgen, B. J., and Best, D. M., 1978. Heat flow in the eastern Caribbean. J. Geophys. Res., 83(B12):5883-5891.

Cox, D. P., Marvin, R. F., M'Gonigle, J. W., McIntyre, D. H., and Rogers, C. L., 1977. Potassium-argon geochronology of some metamorphic, igneous, and hydrothermal events in Puerto-Rico and the Virgin Islands. J. Res. U.S. Geol. Surv., 5(6):689-703.

Dinkelman, M. G., and Brown, J. F., 1977. K-Ar geochronology and its significance to the geological setting of la Désirade, Lesser Antilles. 8th Carib. Geol. Conf. (Curaçao, 1977), 38-39. (Abstract)

Donnelly, T. W., 1975. The geological evolution of the Caribbean and Gulf of Mexico. Some critical problems and areas. In Nairn, A. E. M., and Stehli, F. G. (Eds.), The Ocean Basins and Margins (Vol. 3): New York (Plenum Press), 663-689.

Donnelly, T. W., and Rogers, J. M., 1978. The distribution of igneous rocks suites throughout the Caribbean. Geol. Mijnbouw, 57(2): 151-162.

Donnelly, T. W., and Rogers, J. J. W., 1980. Igneous series in island arcs: the northeastern Caribbean compared with worldwide island arc assemblages. Bull. Volcanol., 43-2:347-382.

Dorel, J., 1978. Sismicité et structure de l'arc des Petites Antilles et du bassin atlantique [thesis]. University of Paris.

1981. Seismicity and seismic gap in the Lesser Antilles arc and earthquake hazard in Guadeloupe. Geophys. Jn. R. Astron. Soc. G.B., 67:679-695.

Dorel, J., Eschenbrenner, S., and Feuillard, M., 1971. Contribution à l'étude sismique de l'arc des Petites Antilles. Ann. Geophys. France, 27(3):295-302.

Fink, L. K., 1968. Marine geology of the Guadeloupe region, Lesser Antilles arc. [Ph. D. dissert.]. University of Miami, Florida. , 1972. Bathymetric and geologic studies of the Guadeloupe region. Lesser Antilles arc. Mar. Geol., 12(4):267-288.

Fink, L. K., Harper, C. T., Stipp, J. J., and Nagle, F., 1971. The tectonic significance of la Désirade-possible relict sea floor crust. 6th Carib. Geol. Conf. (Margarita, 1971), p. 302. (Abstract)

Fox, J. P., and Heezen, B. C., 1975. Geology of the Caribbean crust. In Nairn, A. E. M., and Stehli, F. G. (Eds.), The Ocean Basins and Margins, (Vol. 3): New York (Plenum Press), 421-466.

Fox, P. J., Schreiber, E., and Heezen, B. C., 1971. The geology of the Caribbean crust: Tertiary sediments, granitic and basic rocks from Aves Ridge. Tectonophysics, 12:89-109.

Freeland, G. L., and Dietz, R. S., 1971. Plate tectonic evolution of Caribbean-Gulf of Mexico region. Nature, 232 (July 2):20-23.

Frost, S. H., and Weiss, M. P., 1979. Patch-reef communities and succession in the Oligocene of Antigua, West Indies: summary. Geol. Soc. Am. Bull., 90:612-616.

Gérard, A., Westercamp, D., Bouysse, P., Dubreuil, G., and Varet, J., 1981. Etude de géophysique préliminaire à une évaluation du potentiel géothermique des Antilles françaises (Martinique-Guadeloupe). Doc. Bur. Rech. Géol. Min., France, 27:1-40.

Gunn, B. M., and Roobol, M. J., 1976. Metasomatic alteration of the predominantly island arc igneous suite of the Limestone Caribbees. Geol. Rundschau., 65(3):1078-1108.

Hutton, C. O., 1968. The mineralogy and petrology of Nevis. Leewards Islands, B.W.I. Trans. 6th Carib. Geol. Conf. (Trinidad, $1965)$, pp. $383-388$. 
Jackson, T. A., 1980. The composition and differentiation of the volcanic rocks of Carriacou, Grenadines, West Indies. Bull. Volcanol., 43-2:311-324.

Javet, C., and Alsac, C., 1974. Le volcanisme des Saintes. 7th Conf. Géol. Caraibes, livret-guide. Bur. Rech. Géol. Min. France, pp. 65-75.

Jordan, T. H., 1975. The present-day motions of the Caribbean plate. J. Geophys. Res., 80(32):4433-4439.

Jurdy, D. M., 1979. Relative plate motions and the formation of marginal basins. J. Geophys. Res., 84(B12):6796-6802.

Karig, D. E., 1971. Origin and development of marginal basins in the western Pacific. J. Geophys. Res., 76(11):2542-2561.

1972. Remnant arcs. Geol. Soc. Am. Bull., 83:1057-1068.

1974. Evolution of arc systems in the western Pacific. Ann. Rev. Earth Planet. Sci., 2:51-75.

Keary, P., 1974. Gravity and seismic reflection investigations into the crustal structure of Aves ridge, eastern Caribbean. Geophys. J. R. Astron. Soc. G.B., 38:435-448.

1976. Gravity and seismic reflection investigation into the crustal structure of the Aves ridge, eastern Caribbean. Trans. 7th Conf. Géol. Caraibes (Guadeloupe, 1974), pp. 311-320.

Keary, P., Peter, G., and Westbrook, G. K., 1975. Geophysical maps of the eastern Caribbean. J. Geol. Soc. London, 131:311-321.

Ladd, J. W., 1976. Relative motion of South America with respect to North America and Caribbean tectonics. Geol. Soc. Am. Bull., 87:969-976.

Lameyre, J., and Bowden, P., 1982. Plutonic rock types series: discrimination of various granitoid series and related rocks. $J n$. Volcanol. Geotherm. Res., 14:169-186.

Le Guen de Kerneizon, M., Mascle, A., Maury, R. C., and Westercamp, D., 1979. Les laves de la Désirade (Petites Antilles), témoins d'un magmatisme de marge active: arguments minéralogiques. Bull. Bur. Rech. Géol. Min. France, Sér. IV, 3/4:285-292.

Mc Cann, W. R., and Sykes, L. R., 1981. Subduction of aseismic ridges in the northeastern Caribbean: effects on seismicity and arc morphology. EOC, 62(17):323-324.

Malfait, B. T., and Dinkelman, M. G., 1972. Circum-caribbean tectonic and igneous activity and the evolution of the Caribbean plate. Geol. Soc. Am. Bull., 83:251-272.

Marlow, M. S., Garrison, L. E., Martin, R. G., Trumbull, J. V. A., and Cooper, A. K., 1974. Tectonic transition zone in the northeastern Caribbean. J. Res. U.S. Geol. Surv., 2(3):289-302.

Marsh, B. D., 1979. Island arc development: some observations, experiments and speculations. J. Geol., 87:687:713.

Martin-Kaye, P. H. A., 1969. A summary of the geology of the Lesser Antilles. Overseas Geol. Mineral. Res. G.B., 10(2):172-206.

Mascle, A., Biju-Duval, B., Letouzey, J., Montadert, L., and Ravenne, C., 1977. Sediments and their deformations in active margins of different geological settings. In Sympos. Intern. Geodynamics in SW-Pacific: Paris (Technip), pp. 327-344.

Mattinson, J. M., Fink, L. K., and Hopson, C. A., 1973. Age and origin of ophiolitic rocks on la Désirade island. Lesser Antilles arc. Geophys. Lab., Carnegie Inst. Washington Ann. Rep., pp. 616-623.

1980. Geochronology and isotopic study of la Désirade island basement complex: Jurassic oceanic crust in the Lesser Antilles. Contrib. Mineral. Petrol., 71:237-245.

Mattson, P. H., 1979. Subduction, buoyant braking, flipping, and strikeslip faulting in the northern Caribbean. J. Geol., 87:293-304.

Mattson, P. H., and Pessagno, E. A., 1971. Caribbean Eocene volcanism and the extent of horizon A. Science, 174:138-139.

1979. Jurassic and Early Cretaceous radiolarians in PuertoRican ophiolite-tectonic implication. Geology, 77:440-444.

Meyerhoff, A. A., and Meyerhoff, H. A., 1972. Continental drift IV: the Caribbean plate. J. Geol., 80:34-60.

Molnar, P., and Atwater, T., 1978. Interarc spreading and cordilleran tectonics as alternates related to the age of subducted oceanic lithosphere. Earth Planet. Sci. Lett., 41:330-340.

Nagle, F., 1971. Caribbean geology, 1970. Bull. Mar. Sci., U.S.A., 21(2):375-439.

1972. Rocks from the seamounts and escarpments of the Aves ridge. Trans. 6th Carib. Geol. Conf. (Margarita, 1971), pp. 409-413.
Nagle, F., Stipp, J. J., and Fisher, D. E., 1976. K-Ar geochronology of the Limestone Caribbees and Martinique, Lesser Antilles, West Indies. Earth Planet. Sci. Lett., 29:401-412.

Nemec, M. C., in press. A two phase model for the tectonic evolution of the Caribbean. Trans. 9th Carib. Geol. Conf. (Santo Domingo, 1980).

Odin, G. S. (Ed.), 1982. Numerical Dating in stratigraphy (Vols. 1, 2): New York (John Wiley and Sons Ltd.).

Odin, G. S., and Curry, D., 1981. L'échelle numérique des temps Paléogènes en 1981. C.R. Acad. Sci. France, Sér. II, 293:1003-1006.

Odin, G. S., and Kennedy, W. J., 1982. Mise à jour de l'échelle des temps Mésozoïques. C.R. Acad. Sci. France, Sér. II, 294:383-386.

Peter, G., and Westbrook, G., 1976. Tectonics of southwestern north Atlantic and Barbados ridge complex. Am. Assoc. Pet. Geol. Bull., 60(7):1078-1106.

Ranneft, T. S. M., 1976. Understanding segmentation of island arcs aids exploration. Oil \& Gas J., 15 Nov.:114-118.

Robinson, E., and Jung, P., 1972. Stratigraphy and age of marine rocks, Carriacou, West Indies. Am. Assoc. Pet. Geol. Bull., 56(1): 114-127.

Robson, G. R., and Tomblin, J. F., 1966. Catalogue of the Active Volcanoes of the World. Part XX-West Indies: Rome (Int. Assoc. Volcanol.), pp. 1-56.

Rona, P. A., and Richardson, E. S., 1978. Early Cenozoic global plate reorganization. Earth Planet. Sci. Lett., 40:1-11.

Shipboard Scientific Party, Site 30, 1970. In Bader, R. G., Gerard, R. D., et al., Init. Repts. DSDP, 4: Washington (U.S. Govt. Printing Office), 215-241.

, Site 148, 1973. In Edgar, N. T., Saunders, J. B., et al., Init. Repts. DSDP, 15: Washington (U.S. Govt. Printing Office), 217-275.

Shurbet, D., 1976. Definition of the Caribbean plate by Sn waves from earthquakes. Trans. 7th Conf. Géol. Caraibes (Guadeloupe, 1974), 87-91.

Sigurdsson, H., and Shepherd, J. B., 1974. Amphibole-bearing basalts from the submarine volcano kick'em Jenny in the Lesser Antilles island arc. Bull. Volcanol., 38(4):891-910.

Sigurdsson, H., and Sparks, S., 1979. An active submarine volcano. Nat. Hist., 88(8):38-45.

Sigurdsson, H., Sparks, R. S. J., Carey, S. N., and Huang, T. C., 1980. Volcanogenic sedimentation in the Lesser Antilles Arc. $J$. Geol, 88:523-540.

Simkin, T., Siebert, L., McClelland, L., Bridge, D., Newhall, C., and Latter, J. M., 1981. Volcanoes of the World. Smithsonian Institution: Strondsburg, Pennsylvania (Hutchinson Ross Publ. Co.), pp. 1-235.

Smith, A. L., Roobol, M. J., and Gunn, B. M., 1980. The Lesser Antilles. A discussion of the island arc magmatism. Bull. Volcanol. 43-2:287-302.

Speed, R. C., Gerhard, L. C., and McKee, E. H., 1979. Age of deposition, deformation, and intrusion of Cretaceous rocks, eastern St. Croix, Virgin Islands. Geol. Soc. Am. Bull., 90(1):629-632.

Stoiber, R. E., and Carr, M. J., 1973. Quaternary volcanic and tectonic segmentation of Central America. Bull. Volcanol., 37(3): 304-323.

Tomblin, J. F., 1975. The Lesser Antilles and Aves ridge. In Nairn, A. E. M., and Stehli, F. G., (Eds.), The Ocean Basins and Margins (Vol. 3): New York (Plenum Press), 467-500.

Tovish, A., and Schubert, G., 1978. Island arc curvature, velocity of convergence and angle of subduction. Geophys. Res. Lett., 5(5): 329-332.

Uchupi, E., 1975. Physiography of the Gulf of Mexico and Caribbean Sea. In Nairn, A. E. M., and Stehli, F. G. (Eds.), The Ocean Basins and Margins (Vol. 3): New York (Plenum Press), 1-64.

Uyeda, S., 1982. Subduction zones: an introduction to comparative subductology. Tectonophysics, 81(3-4):133-159.

Uyeda, S., and Kanamori, H., 1979. Back-arc opening and the mode of subduction. J. Geophys. Res., 84(B3):1049-1061.

Walker, B. M., Vogel, T. A., and Ehrlich, R., 1972. Petrogenesis of oceanic granites from the Aves ridge in the Caribbean basin. Earth Planet. Sci. Lett., 15:133-139.

Weeks, L. A., Lattimore, R. K., Harbison, R. N., Bassinger, B. G., and Merrill, G. F., 1971. Structural relations among Lesser Antil- 
les, Venezuela and Trinidad-Tobago. Am. Assoc. Pet. Geol. Bull., 55(10): 1741-1752.

Westbrook, G. K., 1975. The structure of the crust and upper mantle in the region of Barbados and the Lesser Antilles. Geophys. J. R. Astron. Soc., G.B., 43:201-242.

Westercamp, D., 1977. Evolution des séries volcaniques de Martinique et des arcs insulaires des Petites Antilles dans leur contexte structural. 8th Carib. Géol. Conf. (Curaçao, 1977), 227-228. (Abstract)

, 1979. Diversité, contrôle structural et origines du volcanisme récent dans l'arc insulaire des petites Antilles. Bull. Bur. Rech. Géol. Min. France, Sér, IV, 3/4:211-226.

1980. Carte géologique de la Désirade à $1 / 25,000$ et notice explicative. Serv. Géol. Nat., Bur. Rech. Géol. Min. France.
Westercamp, D., and Andreieff, P., in press. Carte géologique à 1/ 20,000 de St Barthélémy et de ses ilets (département de la Guadeloupe) et notice explicative. Serv. Géol. Nat., Bur. Rech. Géol. Min. France.

Westercamp, D., and Mervoyer, B., 1976. Les séries volcaniques de la Martinique et de la Guadeloupe, F.W.I. Bull. Bur. Rech. Géol. Min. France, Sér. IV(4):229-242.

Westermann, J. H., and Kiel, H., 1961. The geology of Saba and St Eustatius, with notes on the geology of St. Kitts, Nevis and Montserrat (Lesser Antilles). Uitg. Naturwetensch. Stu. v. Suriname en de Nederl. Antillen, Utrecht, 24:1-175.

Date of Initial Receipt: July 7, 1982

Date of Acceptance: January 6, 1983 


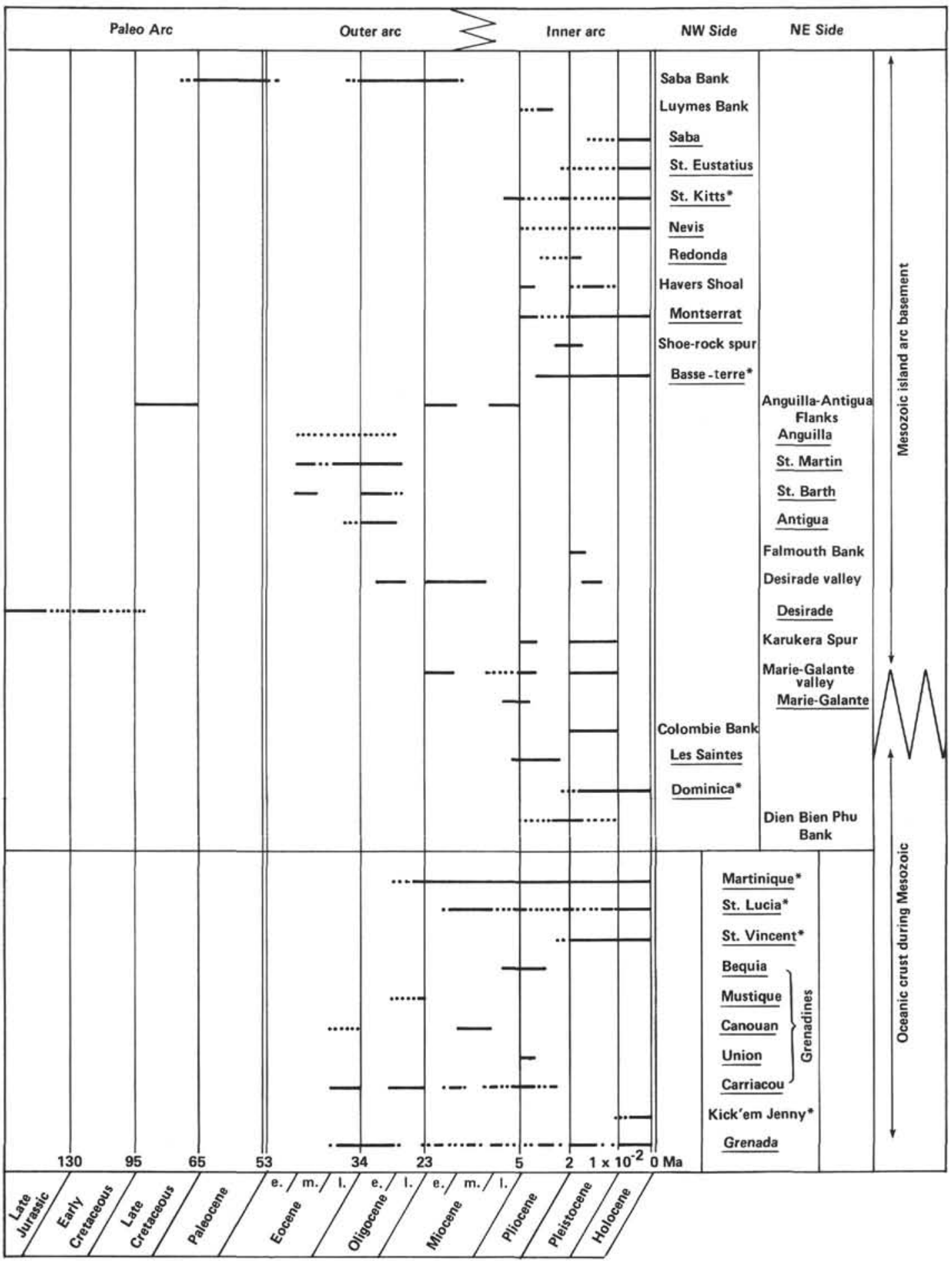

Figure 13. Direct evidence (effusive or intrusive rocks) or indirect evidence (tuffs) of volcanic activity in the Lesser Antilles area, between Late Jurassic and Present, from stratigraphic or radiometric-age data. (Dotted line $=$ assumed activity; asterisk = historic recorded eruptions; submarine features are not italicized. For data sources, refer to the text. Geographic features are listed from north at the top of the figure to south at the bottom, except that the outer (NE side) and inner (NW side) portions of the arc to the north are listed separately. 